\title{
Muhasebe Meslek Mensuplarının Sorunları ve Mesleki Memnuniyetlerinin Analizi: Uşak İli Örneği
}

\author{
Meral GÜNDÜZ* \\ Ercan ÖZEN**
}

\section{ÖZET}

Özellikle son yıllarda ekonomide yaşanan küreselleşme ve teknolojik gelişmelerin etkisiyle, muhasebe mesleğinin standart ve uygulamalarında önemli düzeyde değişme ve gelişmeler meydana gelmiştir. Ancak bir taraftan muhasebe mesleğinin uluslararası standartlara uyum süreci devam ederken, diğer taraftan meslek mensuplarının çözüm bekleyen sorunları bulunmaktadır. Bu çalışmada, Uşak ilinde faaliyet gösteren muhasebe meslek mensuplarının sorunlarının ve bu sorunların çözümüne yönelik beklentilerinin tespit edilmesi amaçlanmaktadır. Ayrıca çalışma kapsamında meslek mensuplarının mesleki memnuniyetleri Kruskall-Wallis testi ile analiz edilmiştir. Çalışma sonuçlar meslek mensuplarının sorunlarının henüz çözülmediğini ve buna rağmen meslek mensuplarının genel olarak mesleklerinden memnun olduklarını göstermektedir.

Anahtar Kelimeler: Muhasebe, Muhasebe Meslek Mensuplarl, Sorunlar, Mesleki Memnuniyet

Jel Sinıflama Kodları: M40, M41, M49

The Analysis of The Issues and Satisfaction of Accounting Professionals: Uşak Case ABSTRACT

Especially in recent years, the globalization and technological developments in the economy have resulted to a significant level of change and results in the standards and practices of the accounting profession. However, compliance with the international standards of the accounting profession on the one hand while continuing the process, on the other hand there are unresolved issues of the members of the accountants. In this study, it is aimed to identify the issues and expectations for the solution of this problems of professional accountants operating in the city of Usak. In addition, the professional satisfaction of the members of accounting profession was analyzed by using Kruskall-Wallis test. The study results, in spite of the issuess yet to be resolved, shows that accounting prrofessionals are generally satisfied with their profession.

Keywords: Accounting, Accounting Professionals, Issues, Professional Satisfaction

Jel Classifications : M40, M41, M49

\footnotetext{
* Yrd.Doç.Dr. Meral Gündüz ,Uşak Üniversitesi, Uygulamalı Bilimler Yüksekokulu, Muhasebe Bilgi Sistemleri Bölümü, meral.gunduz@usak.edu.tr

** Yrd.Doç.Dr. Ercan Özen, Uşak Üniversitesi, Uygulamalı Bilimler Yüksekokulu, Bankacılık ve Finans Bölümü, eozentr@hotmail.com
} 


\section{GíRiş}

Türkiye'de muhasebe mesleğinin yasal bir statüye kavuşturulması 1989 yllında çıkarılan 3568 sayılı kanunla sağlanmıştır. Bu kanunla, muhasebe meslek mensupları; Serbest Muhasebeci (SM), Serbest Muhasebeci Mali Müşavir (SMMM) ve Yeminli Mali Müşavir (YMM) olarak sayılmaktayken, daha sonra yapılan düzenlemeyle Serbest Muhasebecilik unvanı uygulamadan kaldırılmıştır.

Gelişen ekonomik sistem içerisinde muhasebe mesleğinin önemi her geçen gün biraz daha artmaktadır. İşletme ile ilişki içerisinde bulunan bütün taraflar, işletme ile ilgili doğru ve güvenilir bilgilere ihtiyaç duymaktadırlar. Ekonomik ve mali yapının sağlıkı bir şekilde işleyişi için ihtiyaç duyulan bu bilgiler muhasebe meslek mensupları tarafından hazırlanır. (Tuğay ve Tekșen 2014:224).

Kamunun muhasebe mesleğinden önemli beklentileri bulunmaktadır. Bunların başında mükelleflerin vergilemeye esas kazançlarının doğru belirlenmesi ve vergilemede adaletin sağlanması gelmektedir. Bunun yanında vergi kayıp kaçaklarının önlenmesinde de muhasebe meslek mensuplarına sorumluluklar düşmektedir. Bu bakımdan mali müşavirler mükellefler ile devlet arasında iletişimi ve işbirliğini sağlayan bir köprü rolü oynamaktadır. (Organ ve Yegen, 2013:257) Muhasebe meslek mensupları finansal raporlamanın yanı sıra denetim görevini de üstlenerek ekonomik ve mali yapıya önemli bir katkı sağlamaktadırlar.

Son yıllarda muhasebe mesleğine uluslararası standartlar kazandırılmasına yönelik çalışmalar, tüm dünya ülkelerinde olanca hızıyla devam etmektedir. Bu konuda uluslararası sempozyumlar ve kongreler yapılmaktadır. Türkiye'de ise, muhasebe mesleğinin uluslararası standartlara uyum süreci devam etmektedir. Buna rağmen muhasebe meslek mensuplarının sorunları henüz çözülmemiştir.

Muhasebe meslek mensupları kendilerine yüklenen görevleri yaparken mükellefler, yasalar, sosyal yaşam kuralları, kültür veya geleneklerden kaynaklanan nedenlerle bazı sorunlarla karşı karşıya gelebilmektedir. Bu gibi sorunlar bu meslek elemanlarının iş performansını düşürebilmekte, kamuya ve mükellefe verebilecekleri hizmetin kalitesini olumsuz etkileyebilmektedir. Meslek elemanlarının iş ortamının stres verici olması, bu mesleği seçecek genç meslek adaylarının da meslek tercihleri üzerinde etkili olabilmektedir.

Meslek mensuplarının yaşadıkları sorunların çözümü, mesleki faaliyetlerin daha sağlıklı yürütülmesine olanak verecektir. Minimum sorunla yürütülen faaliyetler hem mükellef hem de devlet açısından daha huzurlu bir iş yaşamını ve toplumsal mali uzlaşma ortamını sağlayacaktır.

$\mathrm{Bu}$ çalışma, muhasebe meslek mensuplarının mesleki yaşamda yaşadıkları sorunları ortaya koymayı, literatürle karşılaş̧ırmalar yaparak geçmişten günümüze taşınan sorun olup olmadığını ve yaşanan güncel sorunların neler olduğunu ortaya çıkararak, bu sorunların muhasebecilerin mesleki memnuniyetlerini ne ölçüde etkilediğini belirlemeyi amaçlamaktadır. 


\section{LITERATÜR ARAŞTIRMASI}

Türkçe literatüre bakıldığında son 10 yıllık dönemde farklı bölge ve illerde muhasebe mesleği ve muhasebecilerin sorunlarını araştıran, beklentilerini ortaya koyan çok sayıda akademik çalışmaya rastlanmaktadır. Bu konulardaki ilk çalışmalardan biri Uzay ve Tanç (2004) tarafindan Kayseri ve Nevşehir illerinde gerçekleştirilmiştir. Yazarlar, muhasebecilerin başlıca sorunlarının muhasebe ücretlerinin tahsil edilememesi, geleceğe duyulan güvensizlik, haksız rekabet, yoğun iş yükü ve çok sık değişmesi nedeniyle mevzuatın takip edilememesi olduğunu belirlemişlerdir. Kalaycı ve Tekşen’in (2006) Isparta ilinde yaptıkları çalışmada ortaya koydukları sorunlardan bazıları şunlardır: (i) Mükellef en iyi muhasebeciyi en az vergi ödeten muhasebeci olarak görmektedir. (ii) Muhasebeciler sürekli değişen mevzuatı takip etmede zorlanmaktadır. (iii) Muhasebeciler arasında haksız rekabet bulunmaktadır. (iv) İş yükü çok fazladır. (v) Muhasebeciler hak ettiklerinden daha az ücret almaktadır. (vi) Muhasebeciler vergiye ilişkin konularda maliye ile işbirliği içinde olunmadığını ifade etmektedir.

Alagöz ve Ceran (2007) Konya ilinde yaptıkları çalışmalarında muhasebecilerin ön plandaki sorunlarını; kamu kurumlarında yaşanan sorunlar, ücret kaynaklı sorunlar, aşırı bürokratik işlemler, yeni düzenlemelerle sürekli artan iş yükü, kamu kurumları arasındaki iletişimsizlik, mükellefler tarafından vergi muhasebecisi olarak algılanma olarak siralamaktadir.

Tetik, Kınay ve Ciğer (2008), Antalya ilindeki araştırmalarında il merkezi ve ilçelerinde faaliyet gösteren 121 muhasebe meslek elemanına anket uygulamışlardır. Anket sonuçlarına göre en önemli sorunlar; mükelleflerden istenilen ücretin tahsil edilememesi, eğitilmiş eleman bulamama ve haksız rekabet biçiminde sayılmıştır. Doğu Anadolu bölgesinin 7 ilini kapsayan araştırmasında Bilen (2008) muhasebe meslek elemanlarının yaşadığı en önemli sorunları; tahsilat, kalifiye eleman bulamama, mevzuatın çok sık değişmesi, ücret yetersizliği, belgesiz muhasebecilik işlemleri ve yoğun rekabet olarak belirtmektedir.

Öztürk vd.(2009)'nin Ankara ilinde yaptıkları çalışma, meslek elemanlarının mesleki tükenmişlik olgusunun varlığını duygusal tükenme, kişisel başarıda düşme hissi ve duyarsızlaşma biçiminde ortaya çıkarmaktadır.

Özulucan, Bengü ve Özdemir (2010) Türkiye genelinde 1395 kişilik geniş bir örneklem seçerek yaptıkları çalışmada, ortaya çıkan çok sayıda sorunu şu şekilde gruplandırmışlardır: (i) Meslek mensuplarının mesleklerini icra ederken karşılaştıkları mesleki sorunlar, (ii) Meslek mensuplarının uygulamada karşılaştıkları yetersizliklerle ilgili sorunlar, (iii) Meslek mensuplarının meslek odasından beklentileri ile ilgili sorunlar. Yazarlar bu çalışmalarında; muhasebe ücretlerinin yetersizliği, mevzuattaki gelişmeler, muhasebe standartlarının karmaşıklığı, elektronik ortamda karşılaşılan güçlükler, prim ve vergi ödemelerinde yaşanan sorunlar, meslek mensupları ile akademik çevre arasındaki iletişimin 
sağlıklı olmaması, Maliye ve SGK gibi kurumlarla meslek mensupları arasında yaşanan sorunların ön plana çıktığını belirtmişlerdir.

Bilici ve Aydemir (2011) de Erzurum, Erzincan ve Bayburt illerinde faaliyetlerini sürdüren muhasebe meslek elemanlarına anket uygulayarak muhasebe mesleğinin karş1 karşıya kaldığı sorunları araştırmış ve meslek elemanlarının profilini ortaya koymuştur. $\mathrm{Bu}$ çalışmaya göre, meslek elemanları meslek içi eğitimlerinin \%77'lik kısmını TÜRMOBTESMER programları aracılığıyla aldıklarını, SMMM Odasının verdiği eğitimlerin \%57,8 oranında yeterli görüldüğünü düşünmektedir. Çalışmaya göre, meslek mensuplarının \%54,8'i oranında vergi dairesi ile olan ilişkilerini olumlu karşılamakta iken \%45'i de olumsuz olduğunu düşünmektedir.

Erzurum'da çalışan SMMM'lerin sorunları Yıldırım ve Güney'in de araştırmalarına konu olmuştur. Yildırım ve Güney (2012), tahsilat sorununun devam ettiğini, meslek elemanlarına yüklenen sorumlulukların kendilerine verilen yetkiye kıyasla çok yüksek olduğunu, sıkça çıkan af yasalarının mükellef ile meslek elemanları arasındaki ilişkiyi zedelediğini aktarmıştır.

Karcıoğlu ve Yazarkan (2011) devlet dairelerine teslim edilen dosya ve yazışmalara geç yanıt alındığını ve gereksiz evrak istendiğini belirlemişlerdir. Çalışmaya göre, muhasebe meslek elemanları, devlet dairelerinde çalışan çok sayıda memurun ilgili konularda bilgi bakımından yetersiz olduklarını ve yasaların çok katı olduğunu düşünmektedir.

Biyan (2012) çalışmasında; SMMM'lerin günlük işlerini tamamlayabilmek için, normal çalışma saatlerinden çok daha fazla çalışmak zorunda kaldıklarını, kalifiye eleman bulamadıklarını, tahsilât sorunu ve meslek elemanları arasında haksız rekabet yaşandığını, kanun, tüzük ve yönetmelik gibi yasal düzenlemelerin anlaşılır olmaktan uzak olduğunu, SMMM'lerin \%89,7'inin TURMOB'un meslek elemanlarının haklarını yeterince korumadığını düşündüğünü belirlemiştir.

Ömürbek ve Türkoğlu (2013) da çalışmalarında Biyan (2012) gibi haksız rekabetin önemli boyutta olduğunu ve bu durumun meslek elemanlarını ekonomik ve sosyal açıdan olumsuz etkilendiğini göstermiştir. Yazarlar ayrıca, tahsilât sorununun yaşandığını ve yaşanan sorunların çözümünde mevcut yasal düzenlemelerin yetersiz olduğunu aktarmaktadır. Koç (2011) da çalışmasında tahsilât sorunun çok önemli bir sorun olduğunu vurgulamıştır. Gökgöz ve Zeytin (2012) de çalışmalarında, pek çok çalışmada görülen iş yükünün çok fazla olması, alınan ücretlerin yetersiz olması, devlet dairelerinde bürokratik işlemlerin çokluğu, mükelleflerin evrakını zamanında ulaştırmaması, mükelleflerden muhasebe ücretlerinin zamanında veya hiç tahsil edilememesi şeklindeki sorunları tespit etmişlerdir.

Tuğay ve Tekşen (2014) Burdur ilinde yaptıkları çalışmada önceki araştırmalarda ortaya çıkan sorunlardan pek çoğunun yaşanmaya devam ettiğini belirlemiştir. Bu çalışmada mesleki sorunlar şu şekilde sıralanmıştır: (i)Toplum tarafından en iyi muhasebeci en az vergi ödeten muhasebeci olarak görülmektedir. (ii) Kanunlardaki sık sık yapılan değişikliklerin 
takibinde zorlanılmaktadır. (iii) Bazı meslek elemanları Oda tarafindan belirlenen ücret tarifesinin altındaki bedellerle defter tutmaktadır. (iv) İş yükü fazla ancak alınan ücretler düşüktür. (v) Mali yükümlülükler ve ödemelerden dolayı muhasebe ücretlerinin tahsilatı zorlaşmaktadır. (vi) İnceleme ve denetimlerin sık yapılmasıyla zaman yetersiz gelmektedir.

Genel olarak Türkçe literatüre bakıldığında son on yılda yapılan çalışmaların hemen hepsinde ortak sorunların devam etmekte olduğu görülmektedir. $\mathrm{Bu}$ da bu sorunların çözümüne yönelik olarak ciddi çalışmaların yapılamadığını ilgili kurumlar arasında işbirliklerinin geliştirilemediği sonucunu ortaya koymaktadır.

\section{ARAŞTIRMANIN AMACI}

$\mathrm{Bu}$ çalışmanın amacı, Uşak ilinde faaliyet gösteren muhasebe meslek mensuplarının mesleki faaliyetlerinde karşılaşmış oldukları sorunları, bu sorunların çözümüne yönelik beklentilerini tespit etmek ve belirlenen sorunlar ile doğru mesleği tercih ettiklerini düşünmeleri arasında anlamlı bir farklılığın olup olmadığının araştırılmasıdır.

\section{ARAŞTIRMANIN YÖNTEMI}

Araştırmada, daha önce yapılan akademik çalışmalar değerlendirilmiş, bununla birlikte günümüzdeki gelişmeler ve koşullar dikkate alınarak anket formu tasarlanmıştır. Veri toplama aracı olarak kullanılan anket, iki bölümden oluşmaktadır. Birinci bölümde muhasebe meslek mensuplarının demografik bilgilerine yönelik sorular yer alırken, ikinci bölümde ise muhasebecilik mesleğinde karşılaşılan sorunlara ilişkin önermeler yer almaktadır. Araştırmada sorular, 1= "Kesinlikle katılmıyorum" ile 5= "Kesinlikle katılıyorum" şeklinde seçenekten oluşan 5'li Likert ölçeğine göre hazırlanmıştır.

\section{ARAŞTIRMANIN EVRENI VE ÖRNEKLEMI}

Araştırma evrenini Uşak Serbest Muhasebeci Mali Müşavirler Odasına kayıtlı 323 Serbest Muhasebeci ve Serbest Muhasebeci Mali Müşavir oluşturmaktadır. Ancak bu meslek mensuplarının 182 tanesi aktif olarak çalıştıkları için 182 meslek mensubu evreni temsil eden örneklem alanı olarak belirlenmiştir. Muhasebe meslek mensupları ile yüz yüze görüşülerek anket uygulanmıştır. Ancak 182 meslek mensubundan 140 tanesi anketimize cevap vermiştir. Örneklem ana kütleyi \% 77 oranında temsil etmektedir.

\section{ARAŞTIRMADA KULLANILAN YÖNTEM VE TEKNİK}

Araştırmada veri toplama aracı olarak anket formu düzenlenmiştir. Anket formları, daha sağlıklı sonuçlar alınması amacıyla, bizzat araştırmacılar tarafından meslek mensuplarıyla yüz yüze görüşülerek doldurulmuştur. Uygulanan ve değerlendirmeye alınan anket sayısı 140'dır. Anket verileri frekans analizi yöntemi kullanılarak değerlendirilmiştir.

Ayrıca muhasebe meslek mensuplarının doğru mesleği tercih ettiklerini düşünmeleri ile muhasebe mesleğindeki sorunlar arasında anlamlı bir farklılığın olup olmadığını araştırmak için hipotezler oluşturulmuştur. Oluşturulan hipotezler aşağıda listelenmiştir. 
H1 : Meslek mensuplarının muhasebe mesleğindeki iş yükünün fazla olması ile doğru mesleği tercih ettiklerini düşünmeleri arasında anlamlı bir farklılık yoktur.

H20: Meslek mensuplarının aldıkları ücretin emeklerinin karşılığı olmaması ile doğru mesleği tercih ettiklerini düşünmeleri arasında anlamlı bir farklılık yoktur.

H3 $\mathbf{0}_{0}$ : Meslek mensuplarının mükelleflerden aldıkları ücretlerin zamanında veya hiç tahsil edilememesi ile doğru mesleği tercih ettiklerini düşünmeleri arasında anlamlı bir farkl1lik yoktur.

H4 : $_{0}$ Meslek mensuplarının mükelleflerin ödenecek vergiye ilişkin taleplerinden duydukları rahatsızlık ile doğru mesleği tercih ettiklerini düşünmeleri arasında anlamlı bir farkl111k yoktur.

H50: Meslek mensuplarının mükellef sayısının azlığından dolayı tutulan defter sayılarının az olması ile doğru mesleği tercih ettiklerini düşünmeleri arasında anlamlı bir farkl111k yoktur.

H60: Meslek mensuplarının iş yoğunluğundan dolayı özel hayatlarına zaman ayıramaması ile doğru mesleği tercih ettiklerini düşünmeleri arasında anlamlı bir farklılık yoktur.

H70: Meslek mensuplarının mükelleflerinin evraklarını zamanında ulaştırmamasının işlerini aksatması ile doğru mesleği tercih ettiklerini düşünmeleri arasında anlamlı bir farklılık yoktur.

H8 : $_{0}$ : Meslek mensuplarının sayısının fazlalığından dolayı az defter tutmaları ile doğru mesleği tercih ettiklerini düşünmeleri arasında anlamlı bir farklılık yoktur.

H90: Meslek mensuplarının bazı meslektaşlarının fiyat tarifesinin altında ücretle defter tutmasından duydukları rahatsızlık ile doğru mesleği tercih ettiklerini düşünmeleri arasında anlamlı bir farklılık yoktur.

H10 : Meslek mensuplarının bazı meslektaşlarının alanda yetersiz olmasından olumsuz etkilenmesi ile doğru mesleği tercih ettiklerini düşünmeleri arasında anlamlı bir farkl111k yoktur.

H11 : Meslek mensuplarının kanun ve mevzuattaki değişiklikleri takip etmede zorluk çekmesi ile doğru mesleği tercih ettiklerini düşünmeleri arasında anlamlı bir farklılık yoktur.

H12 : Meslek mensuplarının vergi mevzuatında yapılacak değişikliklerde muhasebecilerin de görüşünün alınması gerektiğini düşünmesi ile doğru mesleği tercih ettiklerini düşünmeleri arasında anlamlı bir farklılık yoktur.

H13 : Meslek mensuplarının devlet dairelerinde bürokratik işlemlerin çokluğundan duydukları rahatsızlık ile doğru mesleği tercih ettiklerini düşünmeleri arasında anlamlı bir farkl1l1k yoktur. 
H140: Meslek mensuplarının vergi ve SGK incelemelerinde denetçilerin olumsuz yanlı tutumlarından duydukları rahatsızlık ile doğru mesleği tercih ettiklerini düşünmeleri arasında anlamlı bir farklılık yoktur.

H150: Meslek mensuplarının vergi incelemelerinde denetçilerin mükellefleri ve muhasebecileri potansiyel suçlu gibi görmeleri ve tehditkar tavırlarından duydukları rahatsızlık ile doğru mesleği tercih ettiklerini düşünmeleri arasında anlamlı bir farklılık yoktur.

H16: Meslek mensuplarının muhasebe standartlarına ilişkin yeterli bilgilendirmelerin yapılmamasının çalışmalarında yetersizliğe neden olması ile doğru mesleği tercih ettiklerini düşünmeleri arasında anlamlı bir farklılık yoktur.

H170: Meslek mensuplarının meslek odasının mevzuattaki değişiklikler hakkında yeterince eğitim vermediği düşüncesi ile doğru mesleği tercih ettiklerini düşünmeleri arasında anlamlı bir farklılık yoktur.

H180: Meslek mensuplarının meslek odasının resmi kurumlarla ilgili karşılaşılan sorunların çözümünde yardımcı olmamasından duydukları rahatsızlık ile doğru mesleği tercih ettiklerini düşünmeleri arasında anlamlı bir farklılık yoktur.

H19: Meslek mensuplarının TÜRMOB tarafından muhasebecinin hakkını savunan muhasebe hukukunun oluşturulmadığı düşüncesi ile doğru mesleği tercih ettiklerini düşünmeleri arasında anlamlı bir farklılık yoktur.

H20 : Meslek mensuplarının TÜRMOB tarafindan muhasebe mesleğinin toplum tarafından tanınması için gerekli çalışmaların yapılmadığı kanaati ile doğru mesleği tercih ettiklerini düşünmeleri arasında anlamlı bir farklılık yoktur.

H210: Meslek mensuplarının KGK'nın muhasebe ve denetim standartlarına ilişkin meslek mensuplarına yönelik yeterince eğitim ve bilgilendirme çalışmaları yapmadı̆̆ ile doğru mesleği tercih ettiklerini düşünmeleri arasında anlamlı bir farklılık yoktur.

$\mathrm{Bu}$ hipotezlerin analiz edilebilmesi için öncelikle değişkenlerin normal dağılım ve homojen varyans ön koşullarını sağlayıp sağlamadığı test edilmiştir. Bunun için ilk olarak birinci koşul olan normal dağılım test edilmek üzere, Tek Örneklem Kolmogorov-Smirnov Testi uygulanmıştır. Kolmogorov-Smirnov Testi iki kümülatif dağılım fonksiyonunun incelenmesi temeline dayanır. Bunlardan birincisi sıfır hipotezinde belirtilen kümülatif dağılım fonksiyonudur. İkincisi örnekten elde edilen gözlenen kümülatif dağılım fonksiyonudur.

Kolmogorov-Smirnov test sonuçlarında Asymp. Sig. değerlerinin 0,05'ten büyük olması durumunda ilgili değişkenin normal dağılıma sahip olduğu söylenebilir. Çalışma kapsamında dikkate alınan 21 değişkenin hiçbirinde bu koşul sağlanamadığından her bir değişken için test puanlarının normal dağılım özelliği göstermediği belirlenmiştir. Bu sonuca göre bütün değişkenler için parametrik olmayan test uygulamasına gidilmesi gerekliliği ortaya çıkmıştır. 
Her bir hipotez için grup sayısı ikiden fazla olduğu için yöntem olarak parametrik olmayan testlerden Kruskal Wallis H testi uygulanmıştır.

\section{ARAŞTIRMANIN BULGULARI}

Araştırma kapsamında elde edilen betimsel ve istatistiki bulgulara temel teşkil eden veriler 7 demografik ve 25 mesleki sorunlara yönelik olmak üzere toplamda 32 adet anket sorusu yardımı ile sağlanmıştır. Ankete katılan muhasebe meslek mensuplarının demografik özellikleri ve karşılaşmış oldukları sorunları, meslek mensuplarının mükelleflerden, devletten, meslek odalarından, TÜRMOB'dan ve KGK'dan beklentileri hakkındaki bilgiler grafikler aracılığılyla gösterilmiştir.

Grafik 1: Cinsiyet

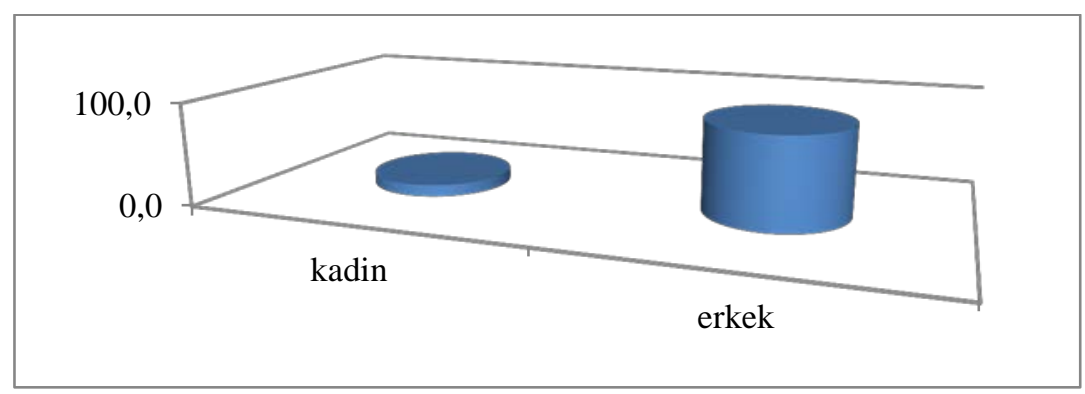

Uşak ilinde faaliyet gösteren muhasebe meslek mensuplarının \%89'unu erkek SMMM'ler teşkil ederken, \% 11 'ini kadınlar oluşturmaktadır.

Grafik 2: Yaş

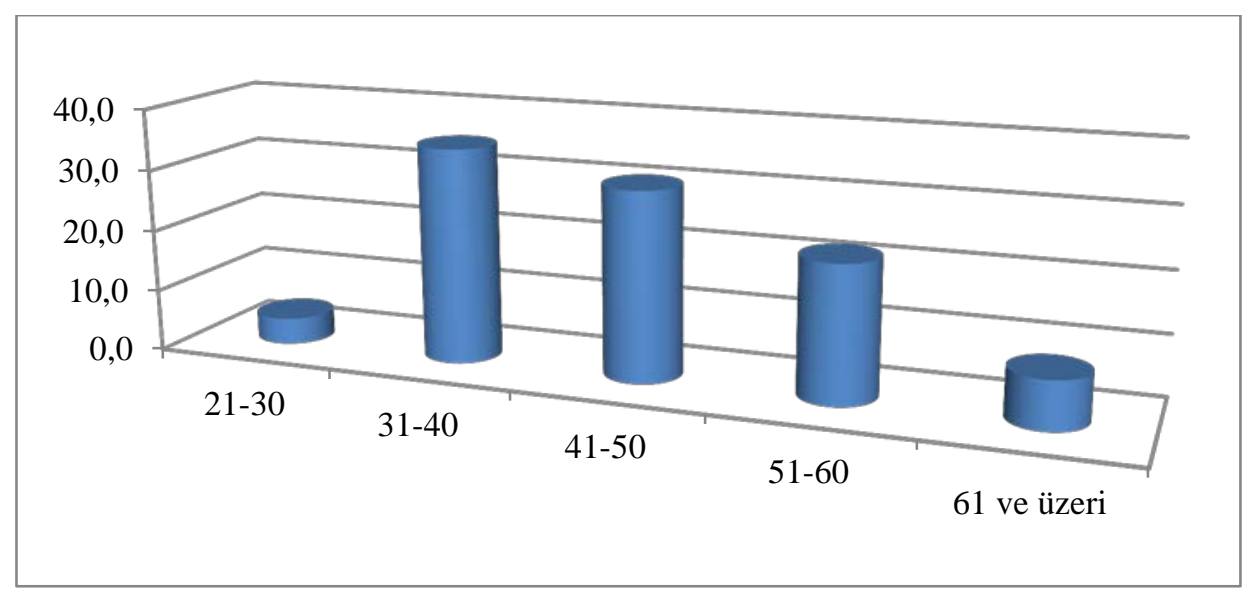

Uşak ilindeki muhesebe meslek mensuplarının \% 4'ü 21-30 yaş arası, \% 35'i 31-40 yaş arası, \% 31'i 41-50 yaş arası, \% 22'si 51-60 yaş arası, \% 8'i ise 61 yaş üzerindedir. Yoğunluk 31-50 yaş arasındadır. Uşak ilinde 21-30 yaş arasının oranının az olması genç nüfusun mesleği tercih etmediği veya yapılan staja başlama ve SMMM sınavlarındaki başarının az olduğunun bir göstergesidir. 
Grafik 3: Medeni Durum

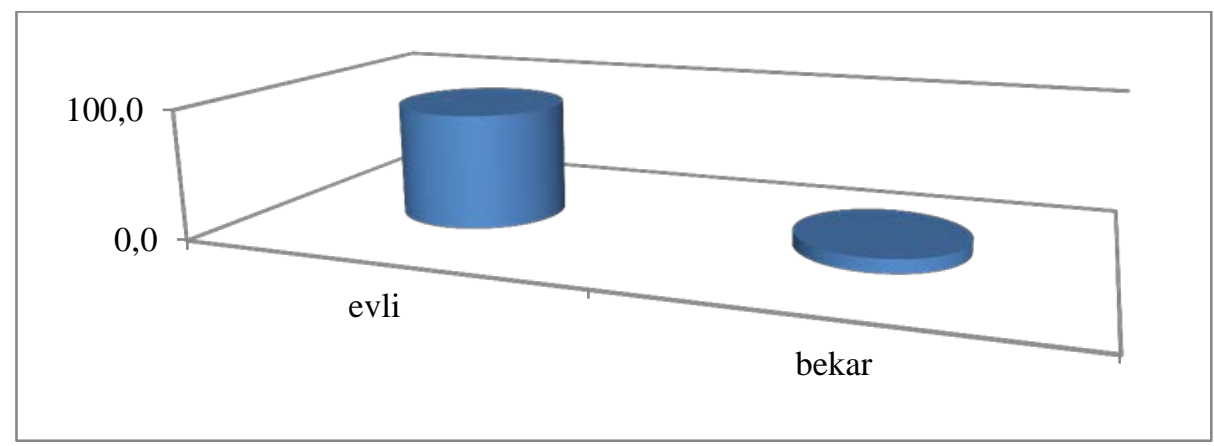

Çalışan muhasebe mensuplarının \% 89'u evli, \% 11'i ise bekardır.

Grafik 4: Eğitim Durumu

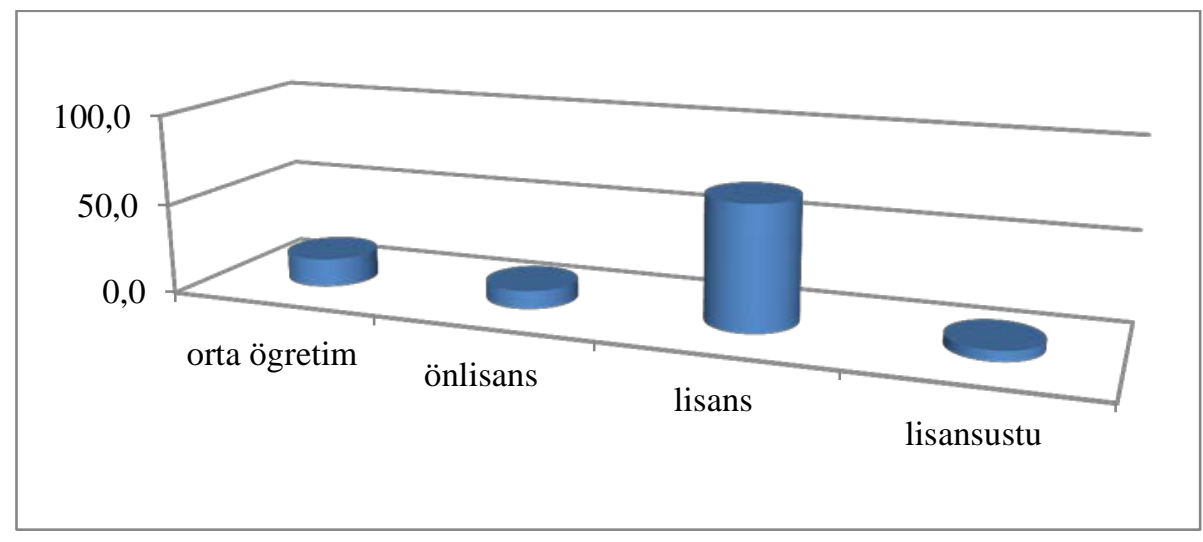

Uşak ilinde faaliyet gösteren muhasebe meslek mensuplarının \% 68'i lisans, \% 10'u önlisans, \%16 's1 ortaöğretim, \% 6's1 ise yüksek lisans düzeyinde eğitime sahiptir. SMMM olabilmek için en az lisans seviyesinde eğitime sahip olunması gerektiği göz önünde tutulursa anketimize katılan muhasebe meslek mensuplarının \% 26'lık kısmının Serbest Muhasebeci olduğu söylenebilir. \% 6 oranında çok az mensup ise yüksek lisans yapmıştır.

Grafik 5: Aylık Gelir

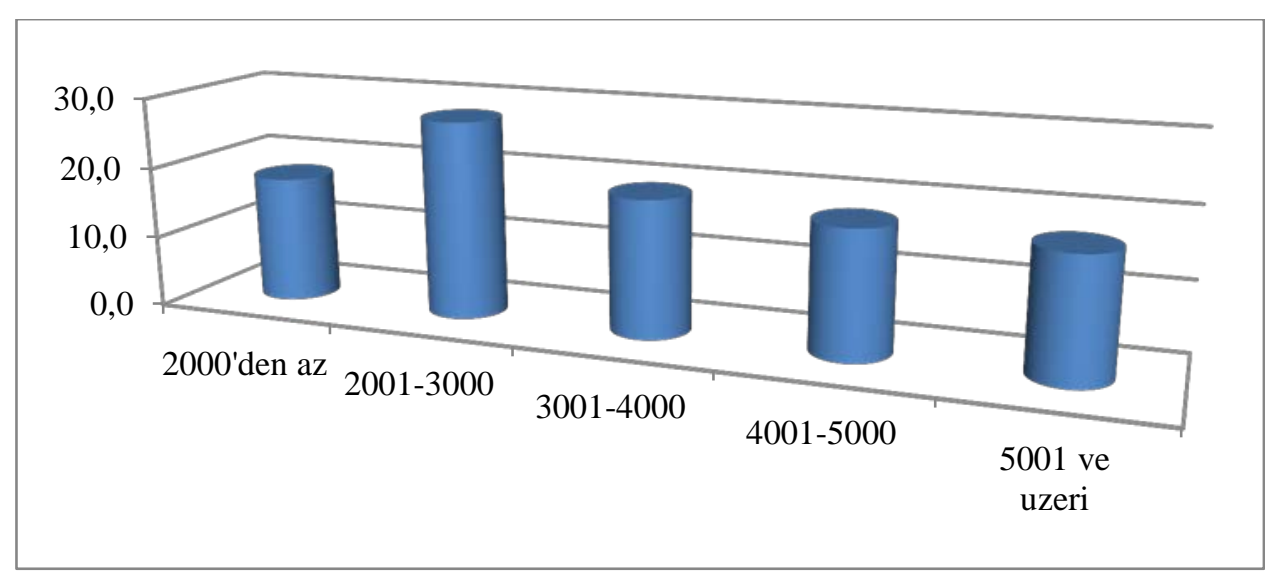


Ankete katılan muhasebe meslek mensuplarının \% 18'i 2.000 liradan az, \% 28'i 2001-3000 lira arasında, \% 19'u 3001-4000 lira arasında, \% 18'i 4001-5000 lira arasında ve $\% 17$ 'si ise 5001 liranın üzerinde aylık gelir elde etmektedirler.

Grafik 6: Çalışma Y11ı

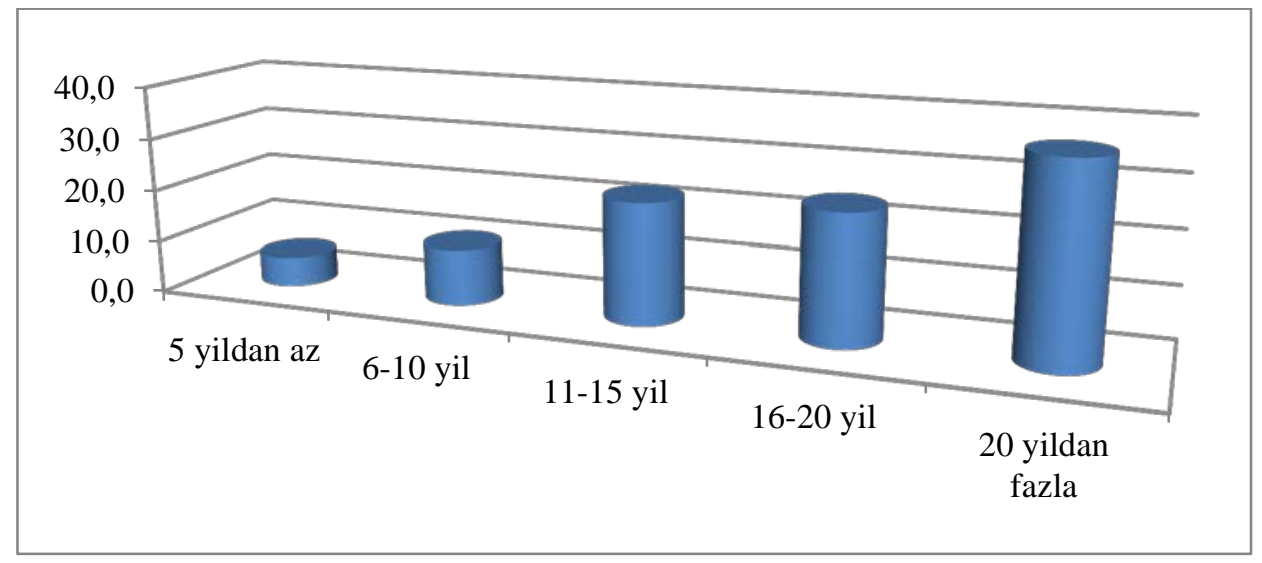

Ankete katılan muhasebe meslek mensuplarının \% 6's1 5 yıldan az, \% 11'i 6 ile 10 yıl arası, \% 23'ü 11 ile 15 yıl arası, \%24 ‘ü 16 ile 20 y1l aras1, \% 36's1 ise 20 yıldan fazla bir süredir bu mesleği sürdürdüklerini belirtmişlerdir. Çalışma yılındaki orana bakarsak son 5 yılda mesleğe katılanların oranının çok düşük olduğunu söyleyebiliriz.

Grafik 7: Çalışma Şekli

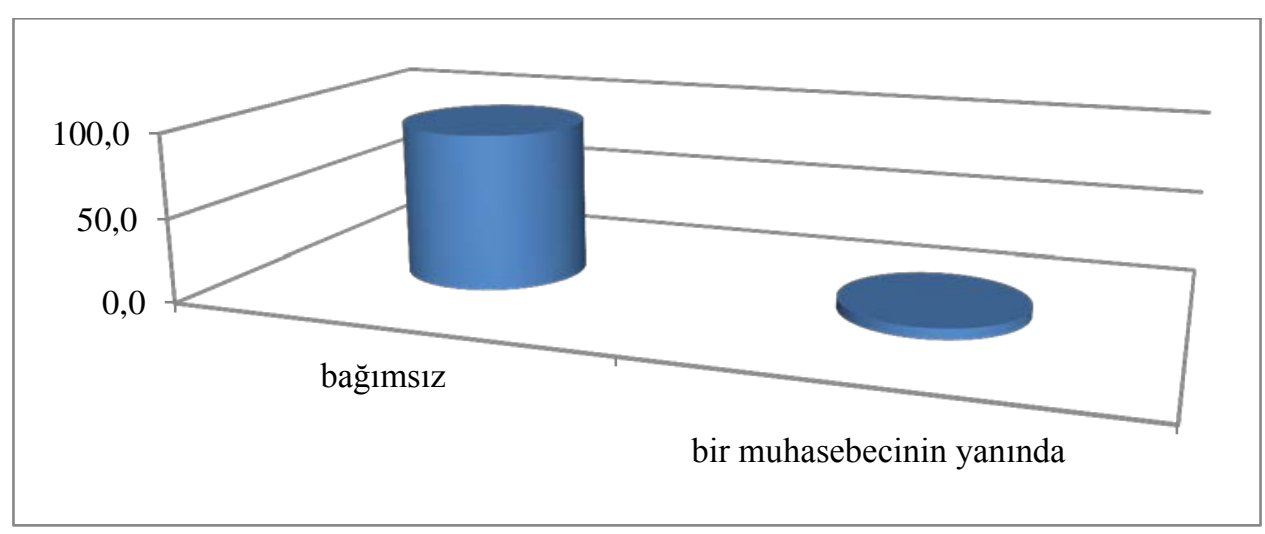

Uşak ilinde faaliyet gösteren ve anketimize katılan muhasebe meslek mensuplarının \% 94'ü bağımsız çalışırken, \% 6 oranında az bir kısım bir başka muhasebe mensubunun yanında çalışmaktadır. 
Grafik 8: Muhasebe Mesleğindeki İş Yükünün Fazla Olduğunu Düşünüyorum

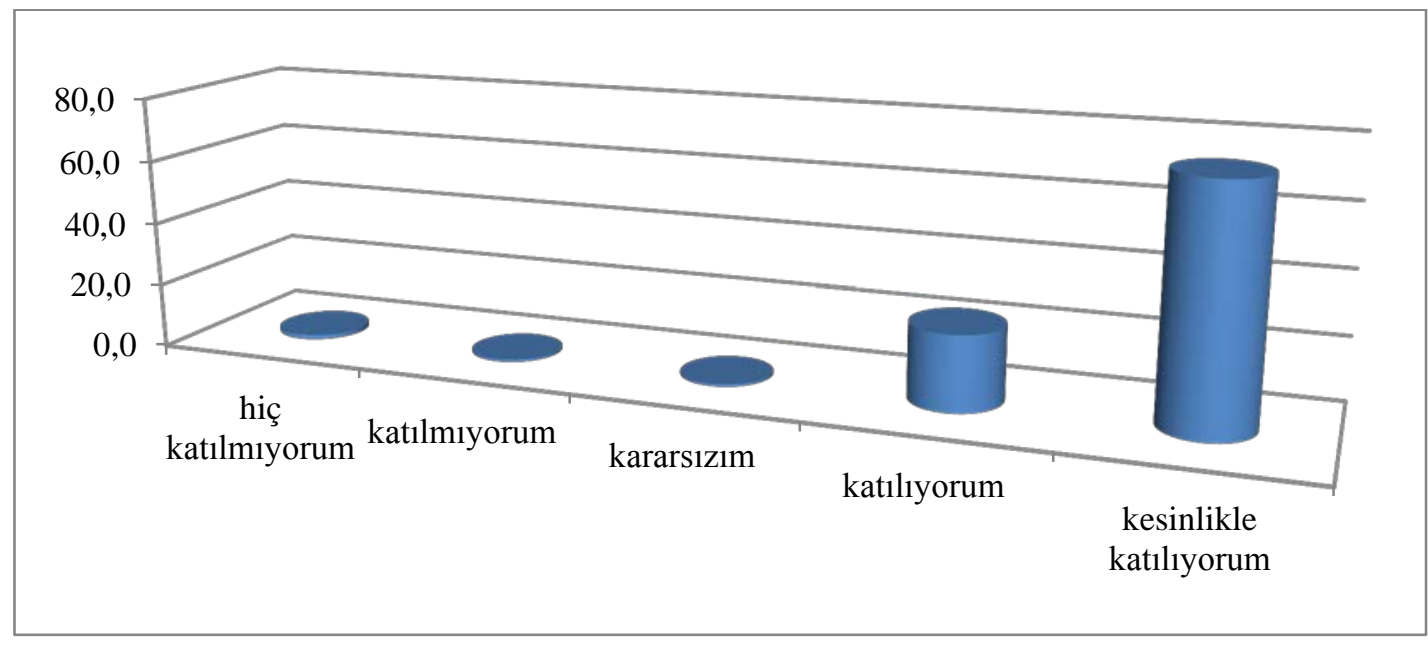

Belirlenen sorunlardan biri muhasebe mesleğindeki iş yükünün fazla olduğunu ifade etmekteydi. Ankete katılan mensuplardan \% 73' ü kesinlikle katıldığını, \% 24' ü katıldığını belirtmişlerdir. \% 3'lük çok az bir kısım ise kararsız, katılmayan ve hiç katılmayanlardan oluşmaktadır. Toplam olarak baktığımızda ankete katılanların \% 97'si muhasebe mesleğinde iş yükünün fazla olduğunu belirtmiştir.

Grafik 9: Alınan Ücretlerin Emeğimizin Karşılığı Olduğunu Düşünmüyorum

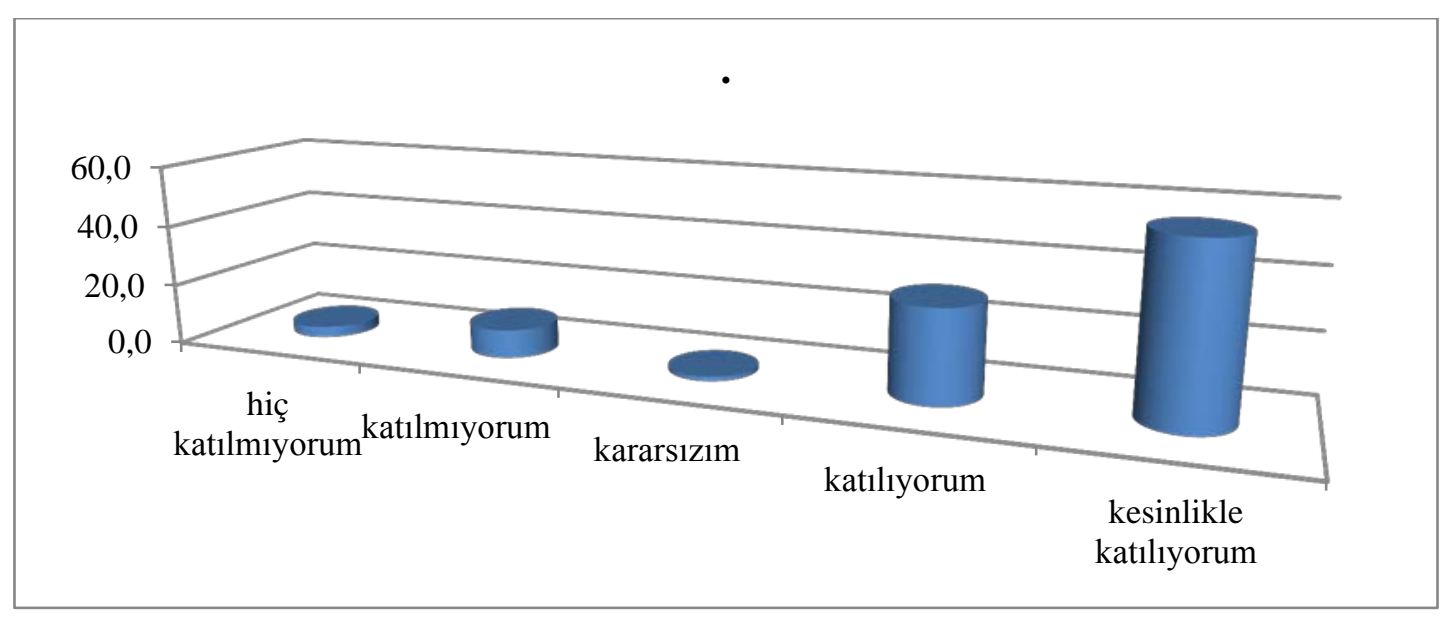

Alınan ücretlerin muhasebe meslek mensuplarının emeklerinin karşılığ olmadığına ilişkin belirlenen soruna, ankete katılanların \% 56'sı kesinlikle katıldığını, \% 30' u katıldığını belirtmiştir. Toplamda ankete katılanların \% 86's1 alınan ücretlerin emeklerinin karşılı̆̆1 olmadığını düşünmektedirler. \% 9'u bu soruna katılmazken \% 4' ü hiç katılmamış, \% 1' i ise kararsız kalmıştır. 
Grafik 10: Mükelleflerden Alınan Ücretlerin Zamanında veya Hiç Tahsil Edilmemesi Beni Rahatsız Ediyor

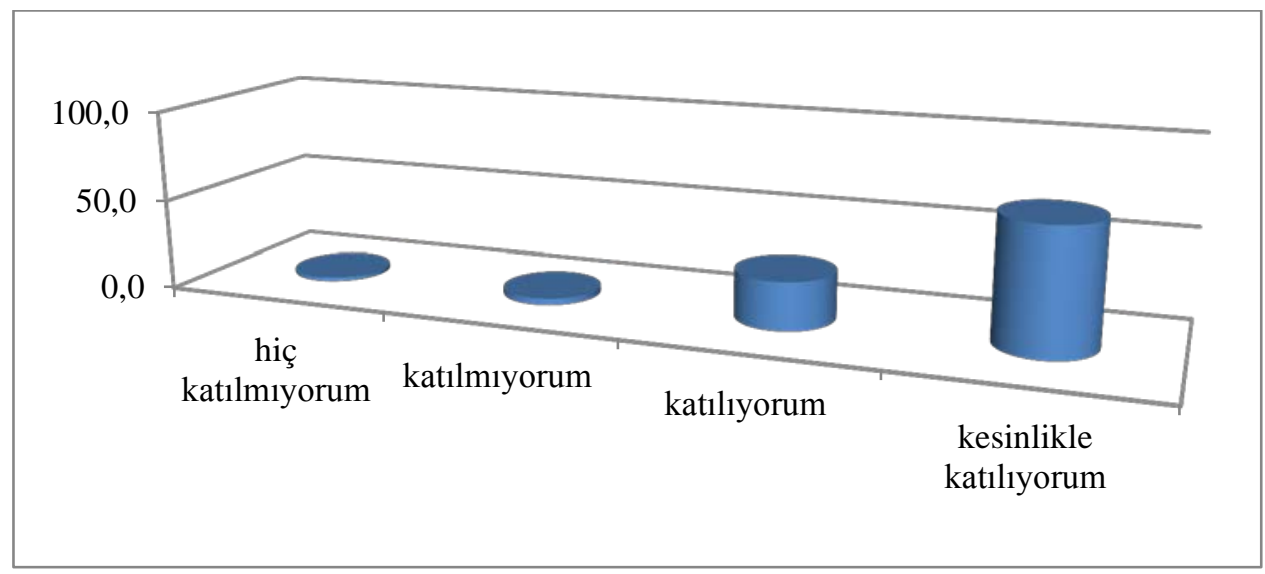

Bir diğer sorun mükelleflerden alınan ücretlerin zamanında veya hiç tahsil edilemediğine ilişkindi. Ankete katılanların \% 68'i kesinlikle katıldığını, \% 26 'sı katıldığını belirtmiş, \% 4'ü katılmadığını, \% 2'si ise hiç katılmadığını ifade etmiştir. Toplamda \% 94'ü mükelleflerden alınan ücretlerin zamanında veya hiç tahsil edilememesinden rahatsızlık duymaktadirlar.

Grafik 11: Mükelleflerin Ödenecek Vergiye İlişkin Talepleri Beni Rahatsız Ediyor

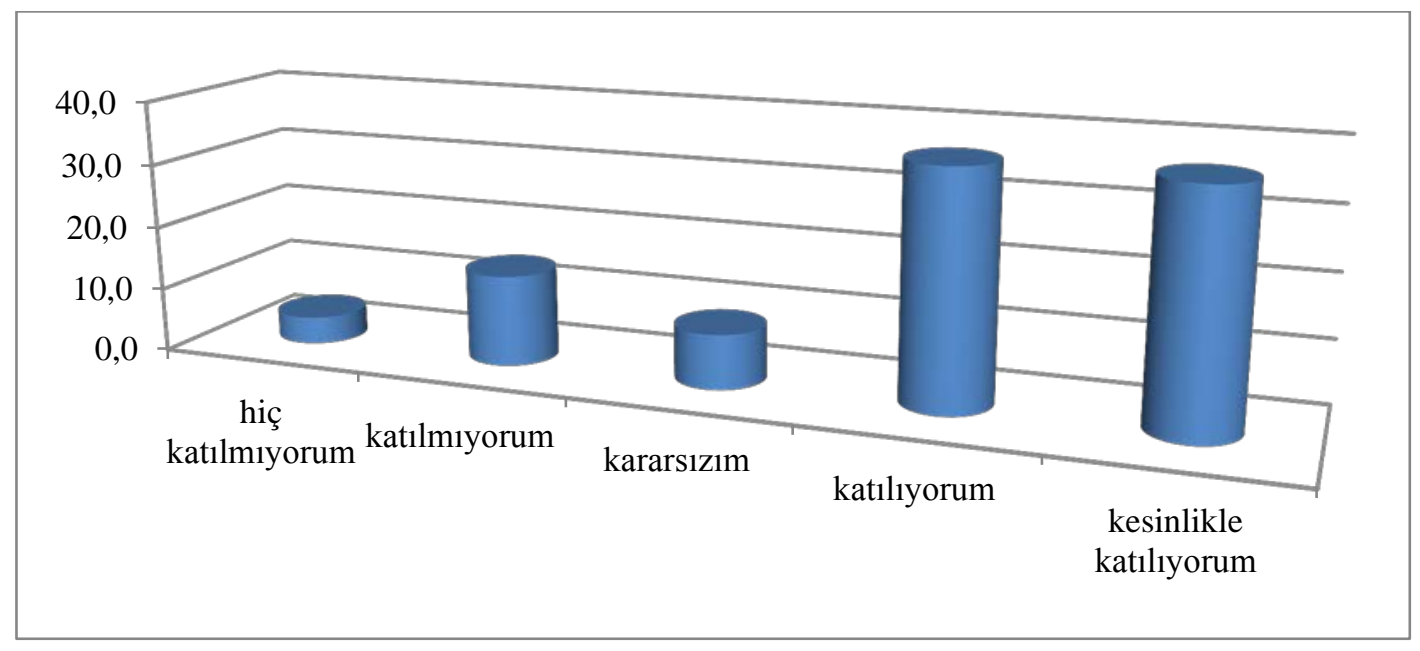

Bir diğer sorun mükelleflerin ödenecek vergiye ilişkin talepleridir. Ankete katılan mensuplardan \% 36'sı bu soruna kesinlikle katıldığını, \% 37'si katıldığını belirtmiş, \% 4'ü hiç katılmamış, \% 14'ü katılmamış, \% 9'u ise kararsız kalmıştır. Toplam olarak \% 73 oranında meslek mensubu mükelleflerin vergiye ilişkin taleplerinden rahatsız olmaktadır. 
Grafik 12: Mükellef Sayısının Azlığından Dolayı Tutulan Defter Sayıları Az Oluyor

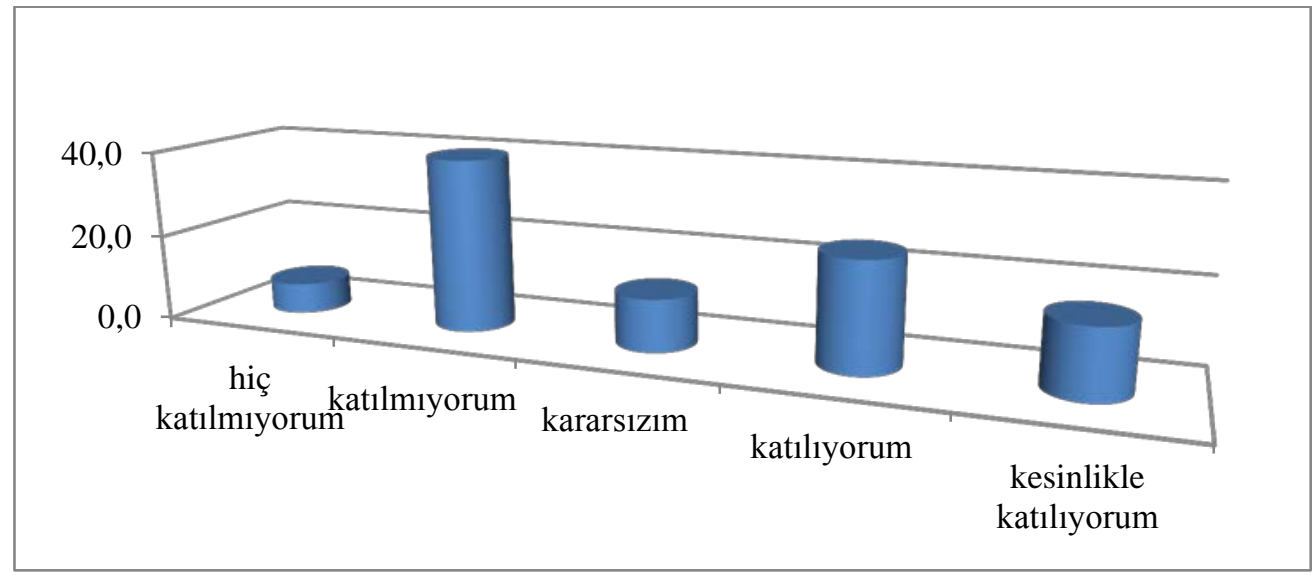

Mükellef sayısının azlığından dolayı tutulan defter sayılarının azlığına ilişkin belirlenen soruna, ankete katılanların \%40' katılmamış, \% 7'si hiç katılmamıştır. \% 12'si kararsız kalırken, \% 25'i katılmış, \% 16'sı ise kesinlikle katılmıştır. \% 47'lik çoğunluk mükellef sayısının tutulan defter sayısının azlığına neden teşkil etmediğini düşünmektedir.

Grafik 13: İş Yoğunluğundan Dolayı Özel Hayatıma Zaman Ayıramıyorum

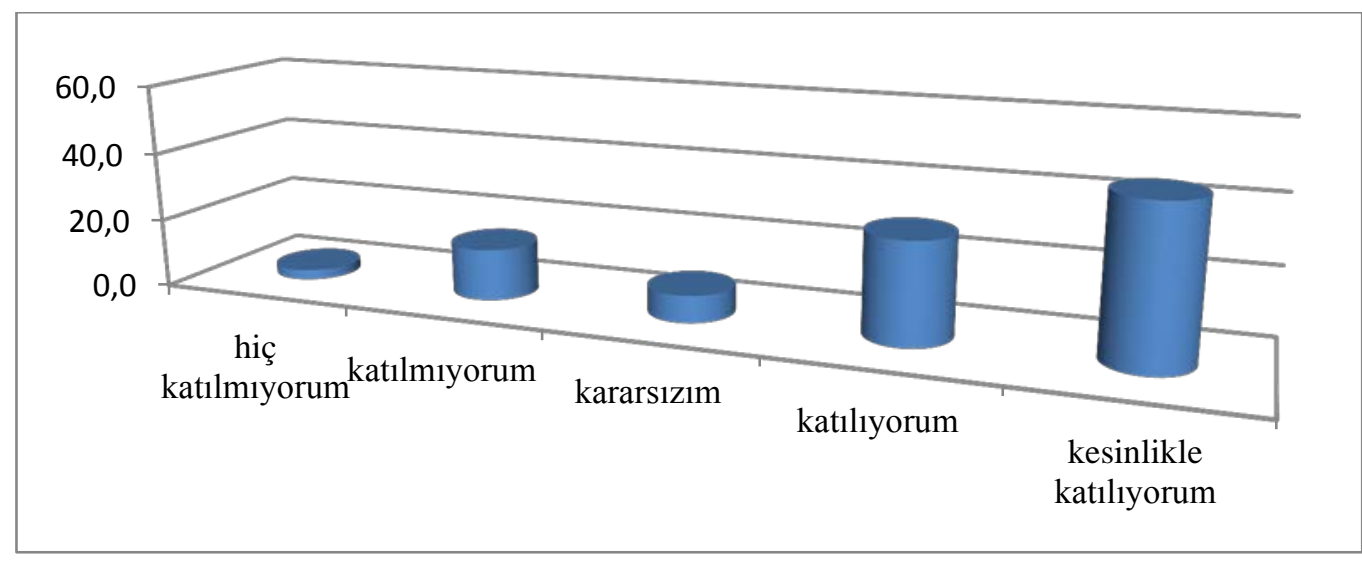

Muhasebe meslek mensuplarının iş yoğunluğunun fazla olmasından dolayı özel hayatlarına zaman ayıramadığına ilişkin belirlenen soruna \% 45 kesinlikle katıldığını, \% 29 katıldığını belirmiştir. \%7,9 luk bir oran kararsız kalırken, \% 3'ü hiç katılmamış, \% 15'i katılmamıştır. Toplam \% 74'lük oranın katılan ve kesinlikle katılanlardan oluştuğuna bakılırsa muhasebe meslek mensuplarının iş yüklerinin fazlalığından dolayı özel hayatlarına zaman ayıramadı̆̆ı söylenebilir. 
Grafik 14: Mükelleflerin Evraklarını Zamanında Ulaştırmaması İşlerimizi Aksatıyor

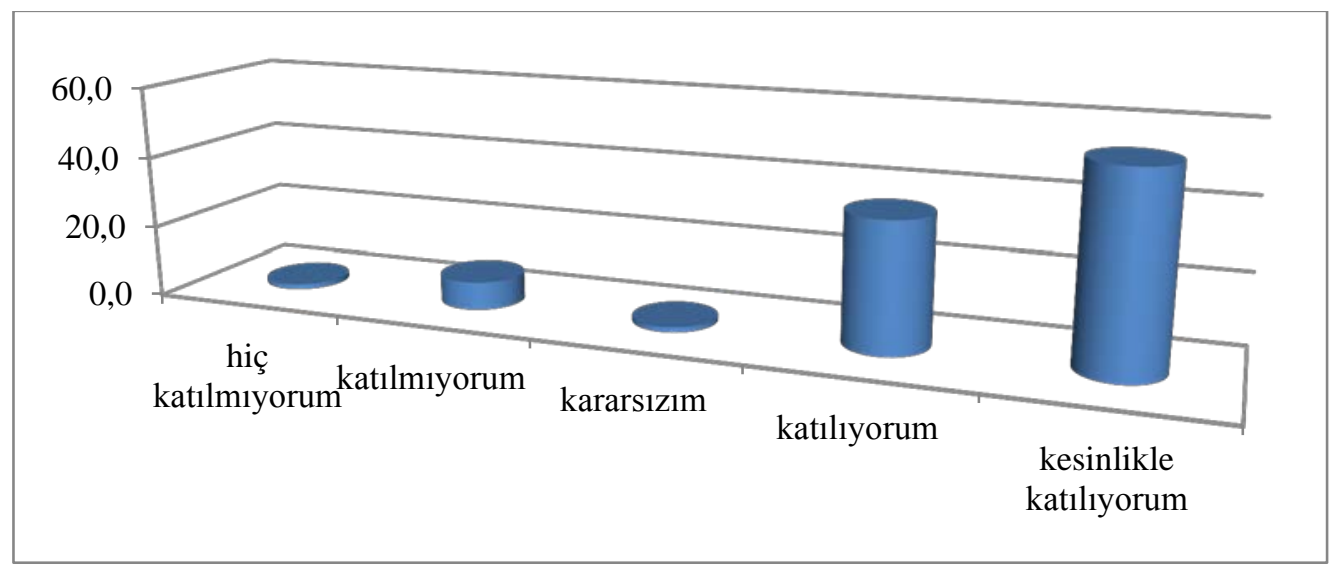

Bir diğer sorun mükelleflerin evraklarını zamanında ulaştırmamasından dolayı muhasebe meslek mensuplarının işlerinin aksamasına ilişkindi. Buna ankete katılanların \% 54'ü kesinlikle katıldıklarını, \% 36'sı katıldıklarını belirtmişlerdir. Toplamda muhasebe meslek mensuplarının \% 90'ı mükelleflerin evraklarını zamanında ulaştırmamasından şikayet etmektedirler. \% 1' i kararsız kalırken \% 9'luk çok az muhasebe mensubu bu görüşe katılmamaktadır.

Grafik 15: Muhasebecilerin Sayısının Fazlalığından Dolayı Az Defter Tutuyorum

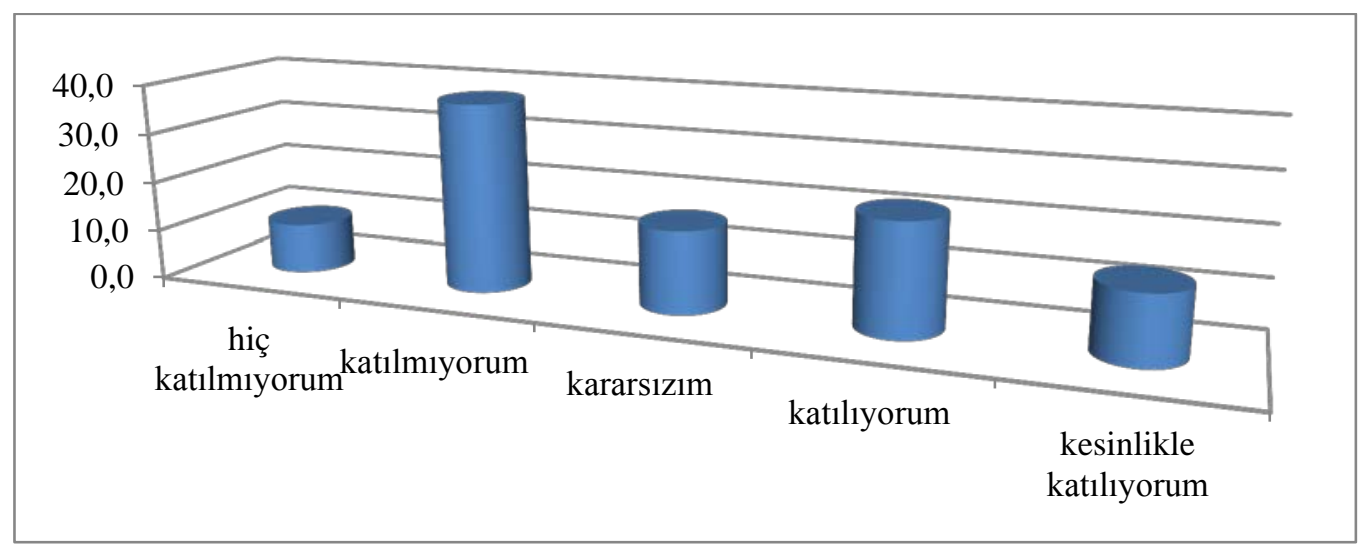

Muhasebeci sayısının fazlalığından dolayı az defter tutulduğuna ilişkin soruna muhasebe meslek mensuplarının \% 38'lik çoğunluğu katılmadığını, \% 10'luk kısmı hiç katılmadığını dile getirmiştir. \% 16'lık kısım kararsız kalırken, \% 14'ü kesinlikle katıldığını, \% 22'lik kısmı katıldığını belirtmiştir. 
Grafik 16: Bazı Meslektaşlarımın Fiyat Tarifesinin Altında Ücretle Defter Tutması Beni Rahatsiz Ediyor

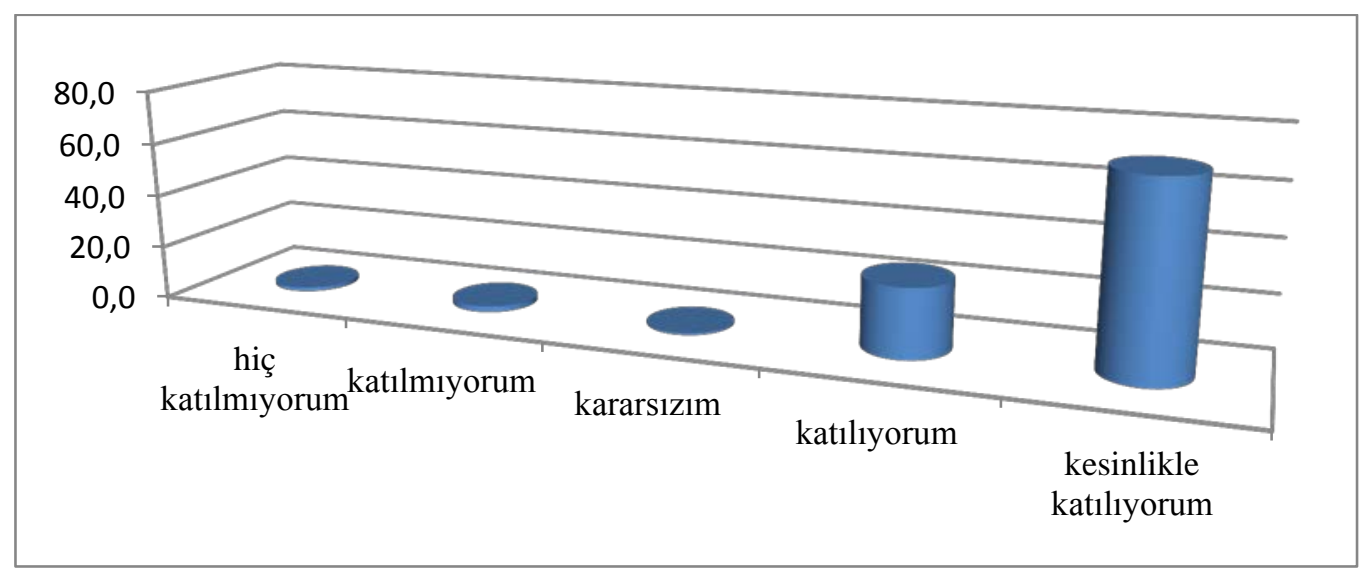

Bazı mensupların fiyat tarifesinin altında ücretle defter tutmasının yarattığı rahatsızlığa ilişkin soruna, \% 70 muhasebe meslek mensubu kesinlikle katılmış, \% 26'lık kısmı katılmıştır. Dolayısıyla ankete katılan mensuplardan \% 96'sı tarifenin altında defter tutulmasindan rahatsızdir.

Grafik 17: Bazı Meslektaşlarımın Alanda Yetersiz Olması Beni Olumsuz Etkiliyor

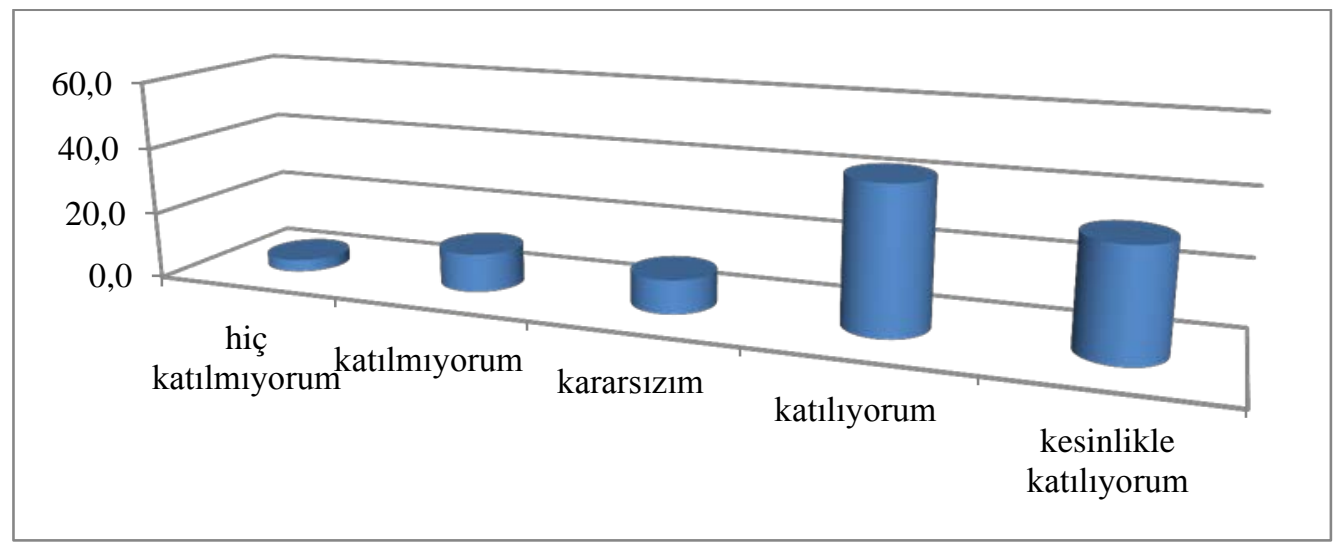

Muhasebe meslek mensuplarının alanında yetersizliğinin kendisini olumsuz etkilediğine ilişkin soruna, ankete katılan muhasebe mensuplarının \% 32'si kesinlikle katılmış, \% 43'ü katılmıştır. \% 75'lik çoğunluk muhasebe meslek mensuplarından bazılarının alanında yetersiz oluşunun kendisini olumsuz etkilediğini belirtmiştir. 
Grafik 18: Kanun ve Mevzuattaki Değişiklikleri Takip Etmede Zorluk Çekiyorum

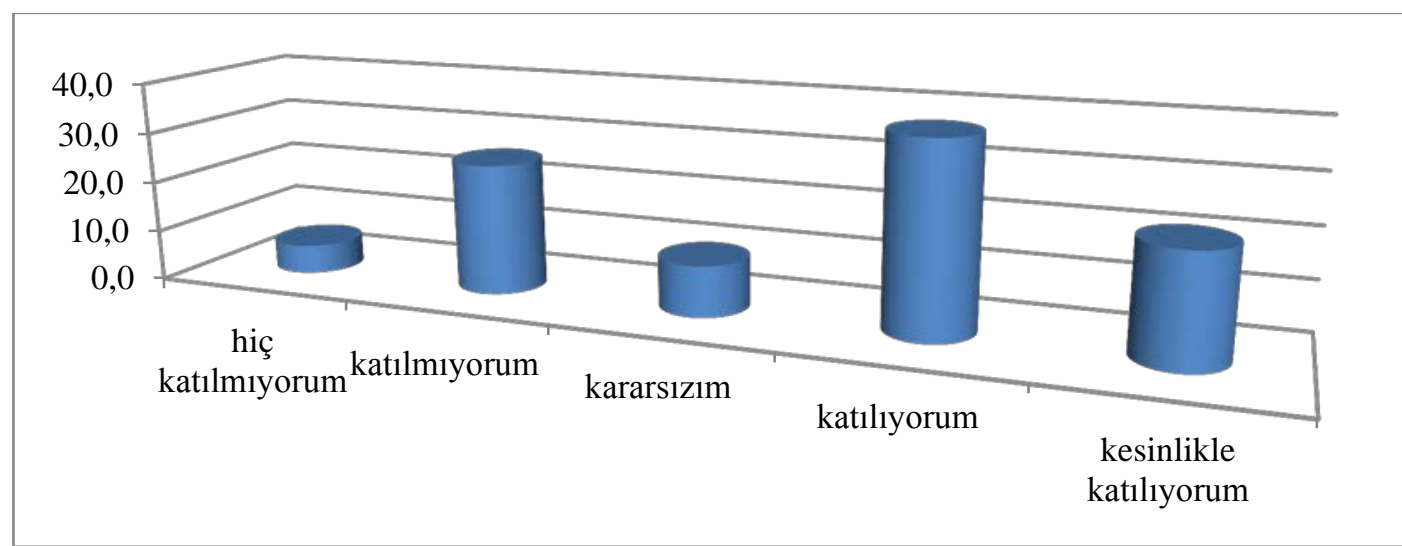

Kanun ve mevzuatta meydana gelen değişiklikleri takip etmede karşılaşılan zorluğu ifade ettiğimiz soruna, ankete katılan muhasebe mensuplarının \% 21'i kesinlikle katılmış, \% 37'si katılmış, 10'u kararsız kalırken, \% 6'sı hiç katılmamış, \% 26'sıda katılmamıştır. Sonuçlara bakarak ankete katılan muhasebe mensuplarının \% 58'lik çoğunluğunun kanun ve mevzuattaki değişiklikleri takip etmede zorluk çektiklerini söyleyebiliriz.

Grafik 19: Vergi Mevzuatında Yapılacak Değişikliklerde Muhasebecilerin de Görüşünün Alınması Gerektiğini Düşünüyorum

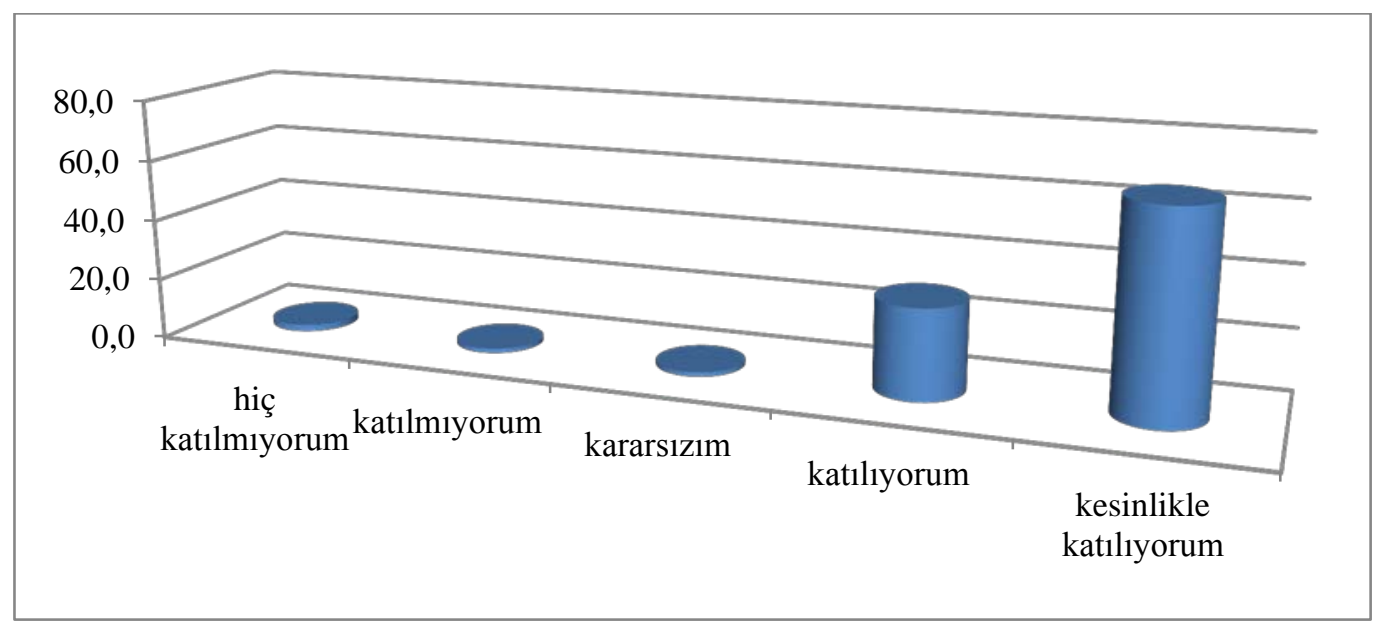

Vergi mevzuatında yapılacak değişikliklerde muhasebecilerin de görüşünün alınması gerektiğine ilişkin beklentiye, ankete katılan muhasebe mensuplarının \% 66'sı kesinlikle katıldığını ve \% 29'u katıldığını belirtmiştir. \% 95'lik çoğunluk vergi mevzuatında değişiklik yapıldığında muhasebecilerinde görüşlerinin alınmasını istemektedirler. 
Grafik 20: Devlet Dairelerinde Bürokratik İşlemlerin Çokluğu Beni Rahatsız Ediyor

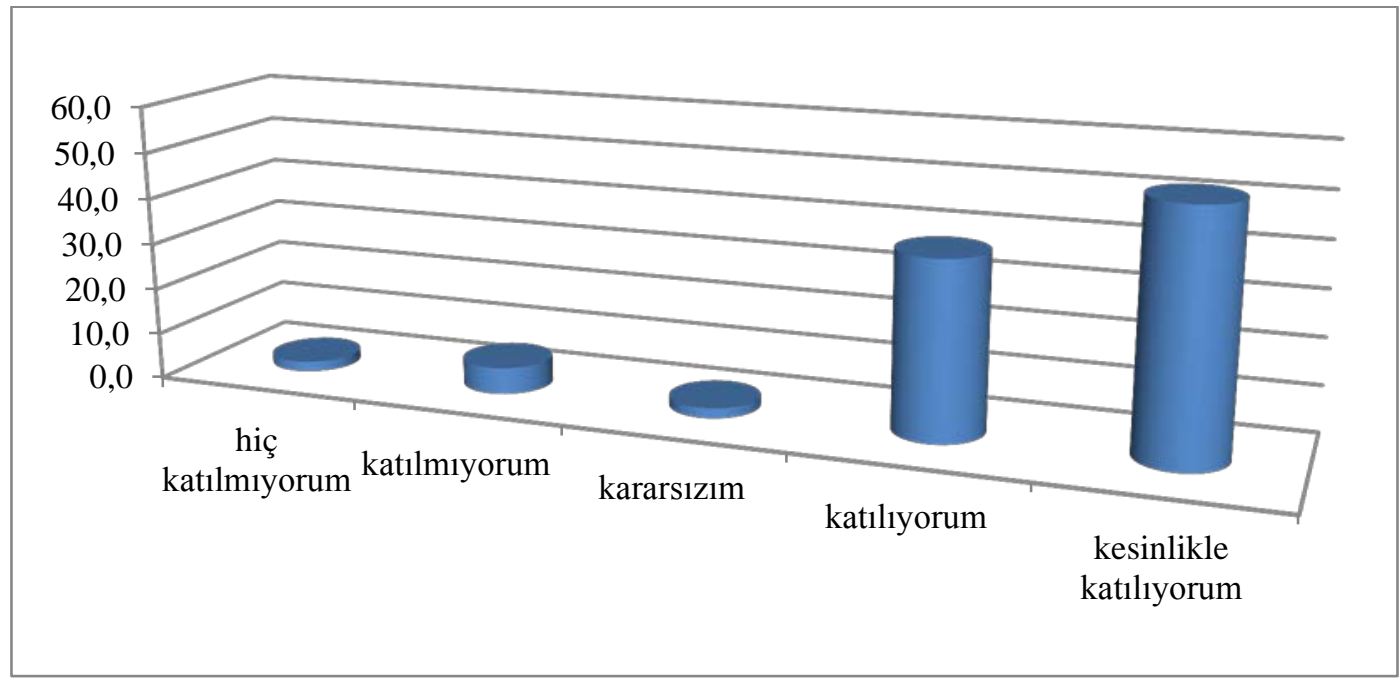

Ankete katılan muhasebe mensuplarının devlet dairesindeki bürokratik işlemlerin çokluğundan rahatsızlığını dile getirdiğimiz soruna , \% 52'si kesinlikle katılmış, \% 38'i katılmıştır. Dolayısıyla \% 90'lık çoğunluk devlet dairelerindeki bürokratik işlemlerin çokluğundan rahatsız olmaktadır.

Grafik 21: Vergi ve SGK İncelemelerinde Denetçilerin Olumsuz Yanlı Tutumları Beni Rahatsız Ediyor

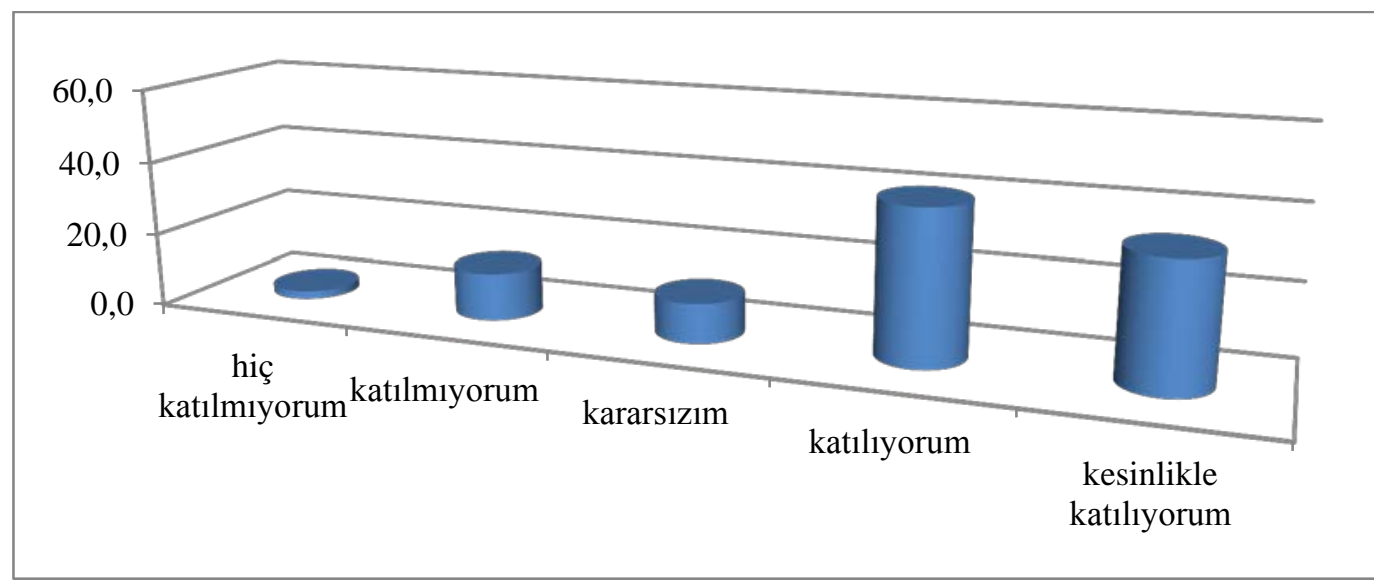

Vergi ve SGK incelemelerinde denetçilerin olumsuz yanlı tutumlarının mensupları rahatsız ettiğine ilişkin soruna, ankete katılan muhasebe mensuplarının \% 33'ü kesinlikle katıldıklarını, \% 41'i katıldığını ifade etmiş, \% 11' kararsız kalırken \% 15' oranında azınlık katılmadığını belirtmiştir. Dolayısıyla ankete katılan muhasebe mensuplarının \% 74'lük çoğunluğu Vergi ve SGK incelemelerinde denetçilerin olumsuz yanlı tutumlarından rahatsızlık duymaktadır. 
Grafik 22: Vergi İncelemelerinde Denetçilerin Mükellefleri ve Muhasebecileri Potansiyel Suçlu Gibi Görmeleri ve Tehditkar Tavırları Beni Rahatsız Ediyor

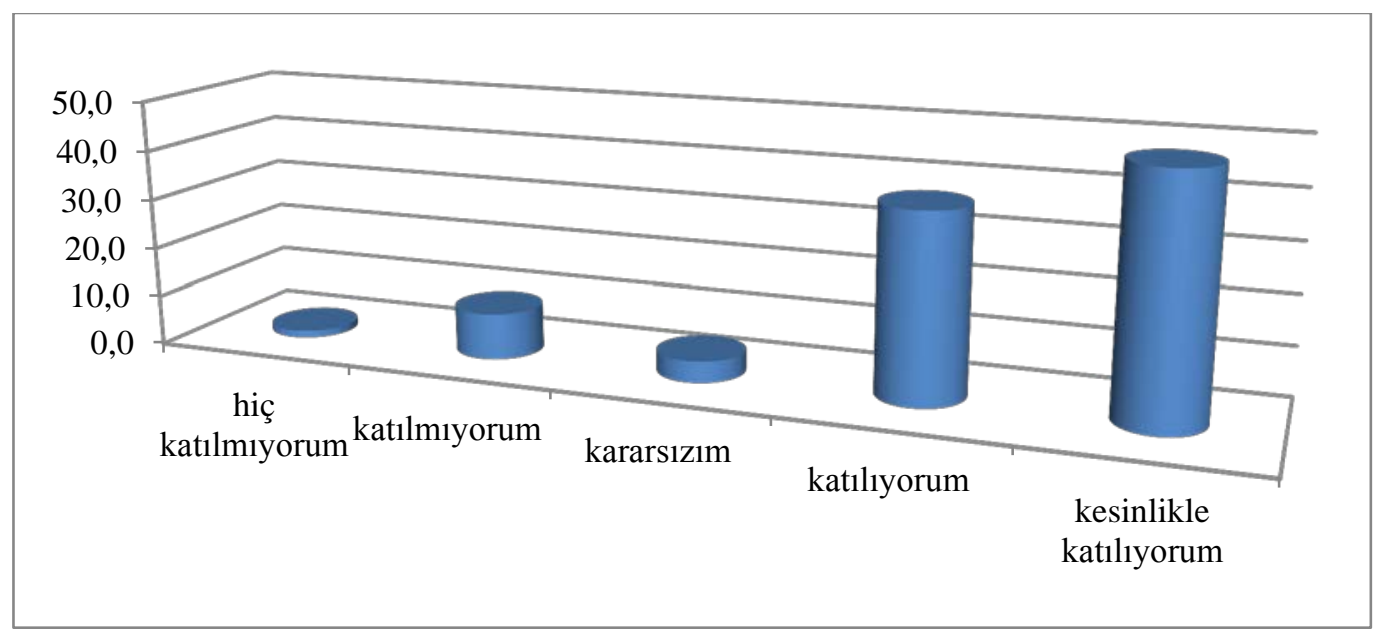

Vergi incelemelerinde denetçilerin mükellefleri ve muhasebecileri potansiyel suçlu gibi görmeleri ve tehditkar tavırlarından kaynaklanan rahatsızlığı dile getirdiğimiz soruna, ankete katılan muhasebe mensuplarının \% 48'i kesinlikle katılmış, \% 37'si katılmıştır. Dolayısıyla \% 85 oranında muhasebe meslek mensubunun bu durumdan rahatsız olduğu söylenebilir.

Grafik 23: Muhasebe Standartlarına Ilişsin Yeterli Bilgilendirmelerin Yapılmaması Çalışmalarımızda Yetersizliğe Neden Oluyor

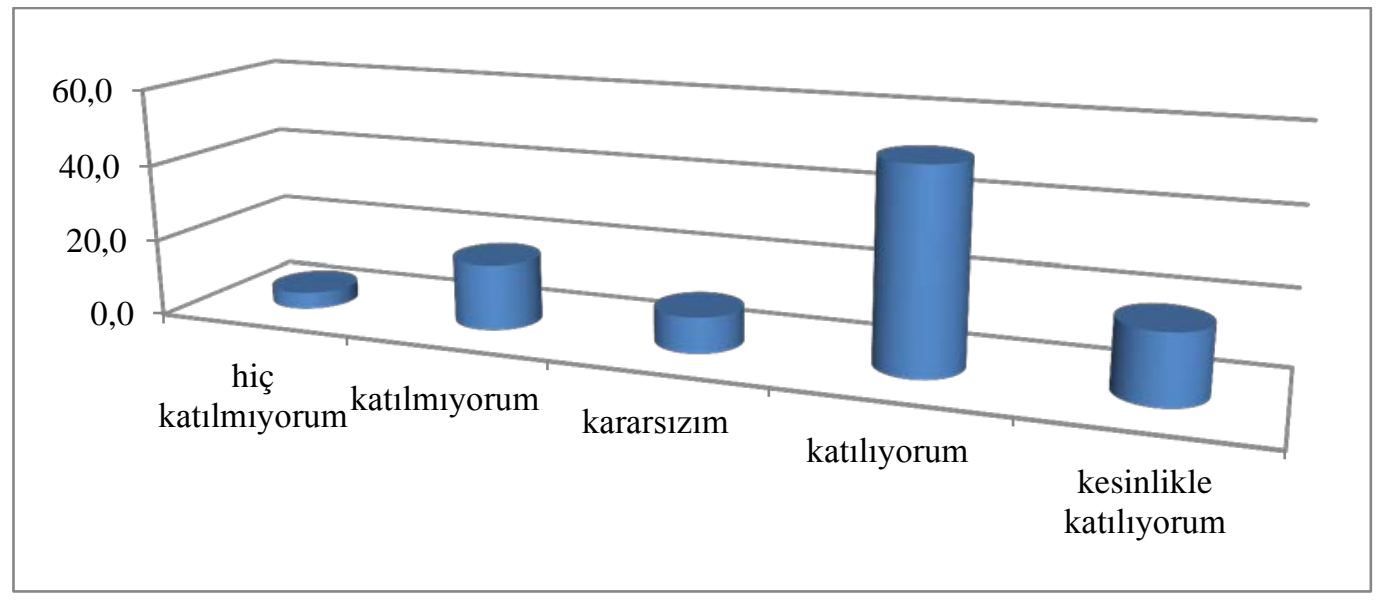

Ülkemizde Kamu Gözetim Kurumu tarafindan son yıllarda muhasebe standartlarına ilişkin yoğun çalışmalar yapılmaktadır. Muhasebe standartlarına ilişkin yeterli bilgilendirmelerin yapılmamasının muhasebe meslek mensuplarının çalışmalarında yetersizliğe neden olmasına ilişkin soruna, \% 18'i kesinlikle katılmış, \% 52'si katılmıştır. \% 9'luk kısım kararsız kalırken, \% 17'si katılmamış, \% 4'ü ise hiç katılmamıştır. 
Grafik 24: Odanın Mevzuattaki Değişiklikler Hakkında Yeterince Eğitim Vermediğini Düşünüyorum

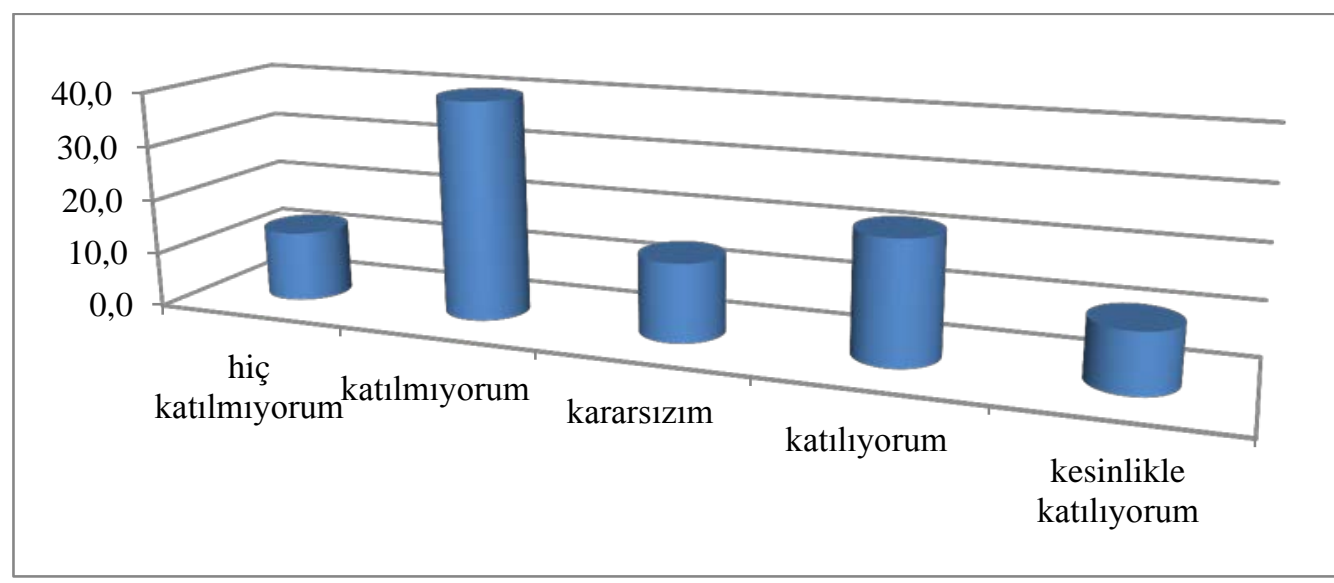

Uşak SMMM'ler Odasının mevzuattaki değişiklikler hakkında yeterince eğitim vermediğine ilişkin belirttiğimiz soruna, ankete katılan muhasebe mensuplarının \% 40'1 katılmadığını, \% 3'ü hiç katılmadığını ifade etmiştir. Toplamda baktığımızda ankete katılan muhasebe mensuplarının Uşak SMMM Odasının yeterince eğitim verdiğini düşünmektedirler.

Grafik 25: TÜRMOB Tarafından Muhasebecinin Hakkını Savunan Muhasebe Hukukunun Oluşturulmadığını Düşünüyorum

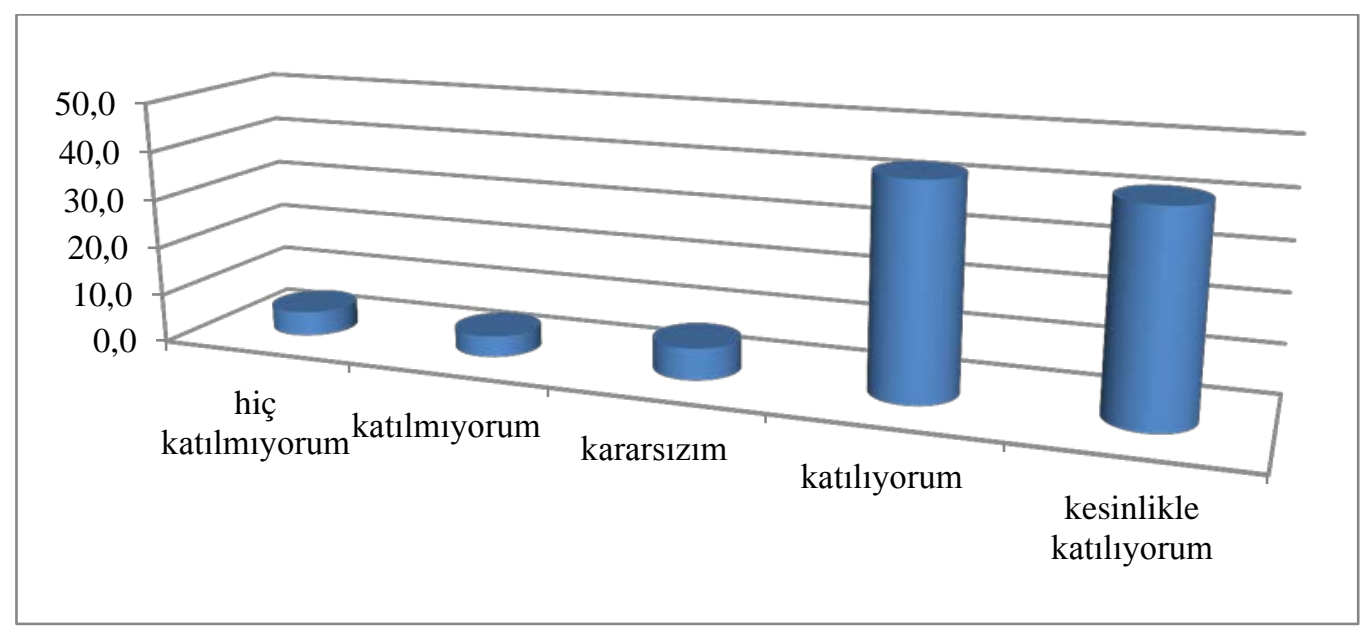

TÜRMOB tarafından muhasebecinin hakkını savunan muhasebe hukukunun oluşturulmadığına ilişkin soruna ankete katılan muhasebe meslek mensuplarının \% 42'si kesinlikle katılıyorum, \% 43'ü ise katıldığını belirtmiştir. Toplam \% 85'lik çoğunluk TÜRMOB'un muhasebecilerin hakkını savunan bir muhasebe hukukunun oluşturulmadığı kanaatindedirler. 
Grafik 26: TÜRMOB Tarafından Muhasebe Mesleğinin Toplum Tarafından Tanınması İçin Gerekli Çalışmaların Yapılmadığı Kanaatindeyim

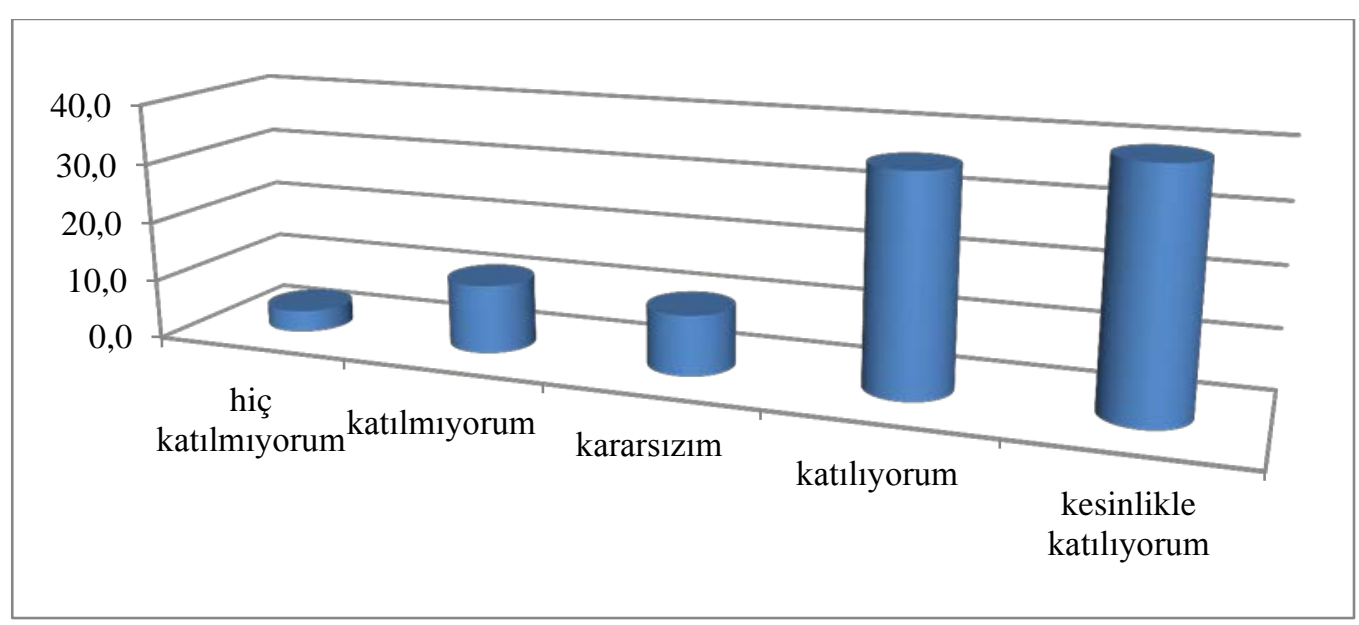

TÜRMOB tarafından mesleğin toplum tarafından tanınması için gerekli çalışmaları yapmadığına ilişkin soruna, ankete katılan muhasebe meslek mensuplarının \% 39'u kesinlikle katılmış, \% 36'sı katılmıştır. Muhasebe meslek mensuplarının \% 75'i TÜRMOB'un muhasebe mesleğinin tanınması için gerekli çalışmaları yapmadığını düşünmektedirler.

Grafik 27: KGK'nin Muhasebe ve Denetim Standartlarına Ilişkin Meslek Mensuplarına Yönelik Yeterince Eğitim ve Bilgilendirme Çalışmaları Yaptığını Düşünmüyorum

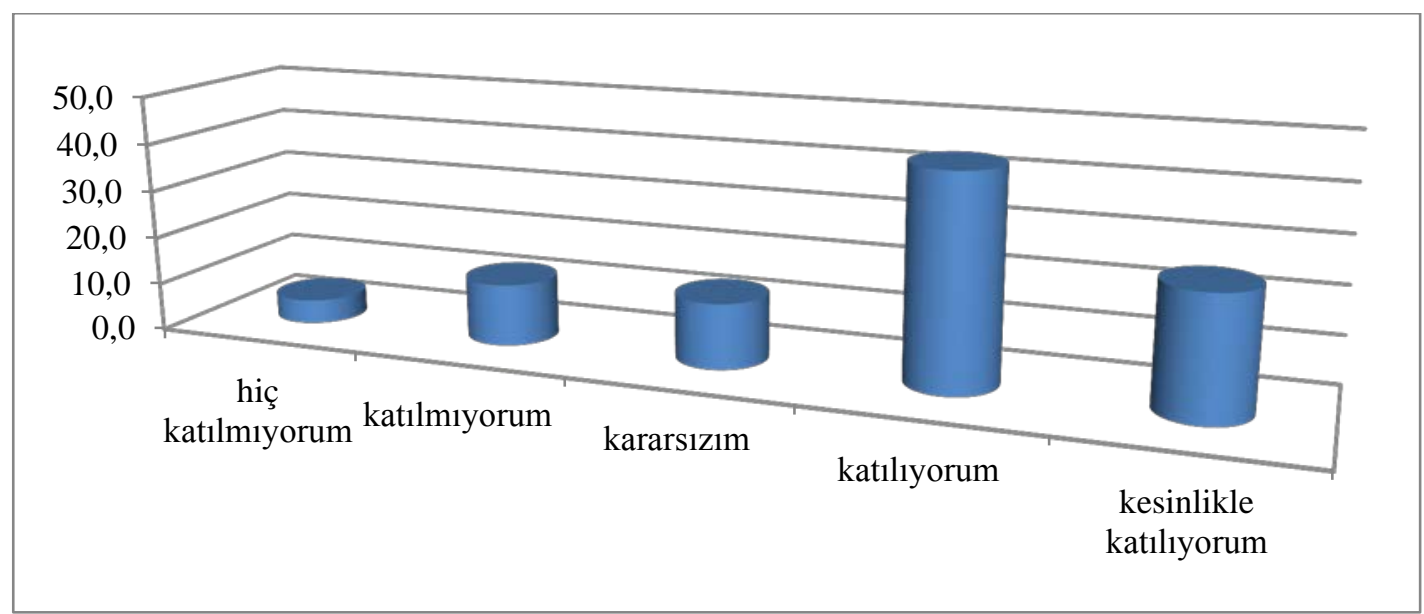

Kamu Gözetim Kurumu’nun muhasebe ve denetim standartlarına ilişkin meslek mensuplarına yeterince eğitim ve bilgilendirme çalışmaları yapmadığına ilişkin belirlenen soruna, ankete katılan muhasebe meslek mensuplarının \% 25'i kesinlikle katıliyorum, \% 43' ü katılıyorum şeklinde cevap vermiştir. \% 14'ü kararsız kalırken, \% 5'i hiç katılmamış, \% 13'ü katılmamıştır. \% 68'lik çoğunluk KGK'nın muhasebe ve denetim standartlarına ilişkin eğitim ve bilgilendirme çalışmaları beklentisi içindedirler. 
Grafik 28: Doğru Mesleği Seçtiğimi Düşünüyorum

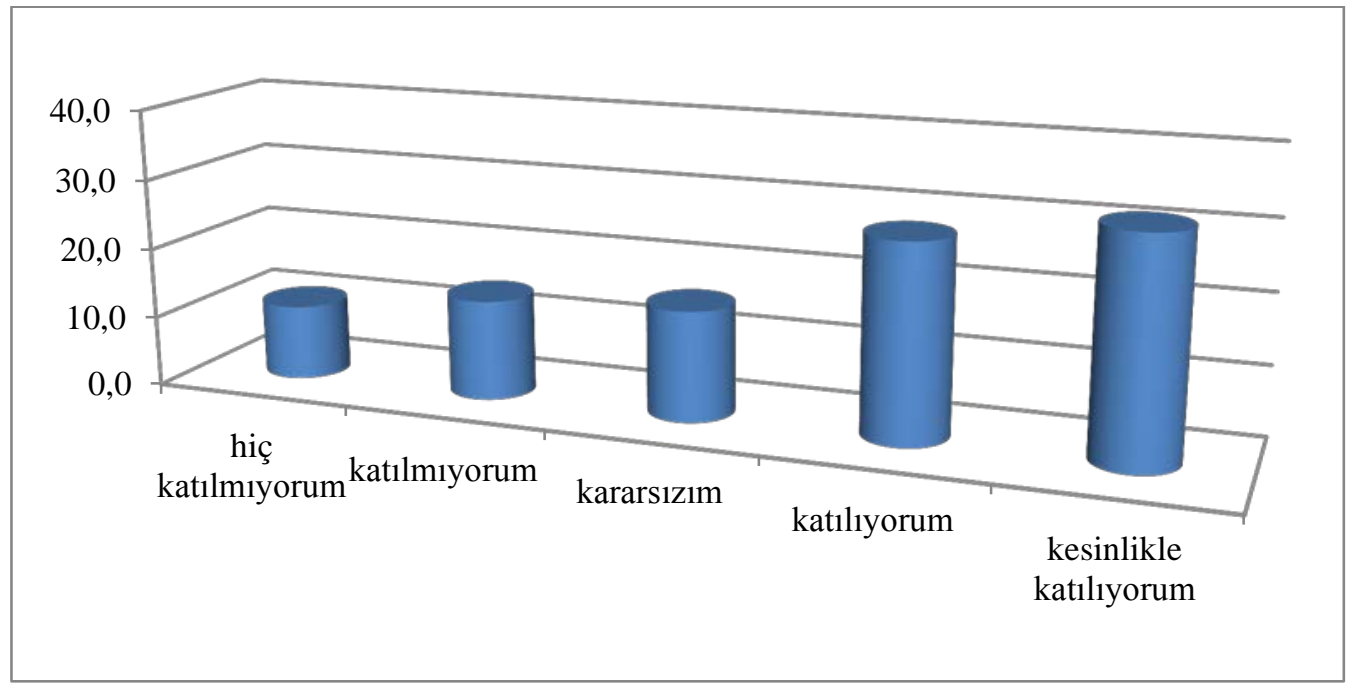

Son olarak araştırmaya katılan muhasebe meslek mensuplarının meslek memnuniyetlerinin ölçülmesi amacıyla ankete son bir madde eklenmiştir. "Doğru mesleği seçtiğimi düşünüyorum" Buna ankete katılan muhasebe meslek mensuplarının \% 31'i kesinlikle katılıyorum, \% 28'i katılıyorum, \% 16'sı kararsız kalırken \% 11'i hiç katılmıyorum, \% 14'ü ise katılmıyorum şeklinde cevap vermiştir. Uşak ilinde ankete katılan muhasebe meslek mensuplarından \% 59'u doğru mesleği seçtiğini düşünürken, \% 25'i doğru mesleği seçtiğini düşünmemektedir.

Tablo 1: Kruskal Wallis H-Testi

\begin{tabular}{|l|r|r|r|}
\hline & Chi-Square & df & Asymp. Sig. \\
\hline H1 & 5.008 & 2 & 0.082 \\
\hline H2 & 6.294 & 2 & $\mathbf{0 . 0 4 3}$ \\
\hline H3 & 7.075 & 2 & $\mathbf{0 . 0 2 9}$ \\
\hline H4 & 4.442 & 2 & 0.108 \\
\hline H5 & 1.66 & 2 & 0.436 \\
\hline H6 & 2.785 & 2 & 0.248 \\
\hline H7 & 4.931 & 2 & 0.085 \\
\hline H8 & 2.918 & 2 & 0.232 \\
\hline H9 & 0.659 & 2 & 0.719 \\
\hline H10 & 2.27 & 2 & 0.321 \\
\hline H11 & 4.064 & 2 & 0.131 \\
\hline H12 & 0.055 & 2 & 0.973 \\
\hline H13 & 3.253 & 2 & 0.197 \\
\hline H14 & 2.069 & 2 & 0.355 \\
\hline H15 & 0.43 & 2 & 0.807 \\
\hline H16 & 3.844 & 2 & 0.146 \\
\hline H17 & 0.953 & 2 & 0.621 \\
\hline H18 & 0.049 & 2 & 0.976 \\
\hline H19 & 1.406 & 2 & 0.495 \\
\hline H20 & 1.138 & 2 & 0.566 \\
\hline H21 & 2.095 & 2 & 0.351 \\
\hline
\end{tabular}


Ayrıca muhasebe meslek mensuplarının doğru mesleği tercih ettiklerini düşünmeleri ile muhasebe mesleğindeki sorunlar arasında anlamlı bir farklılığın olup olmadığını araştırmak amacıyla Kruskal Wallis H-Testi sonuçlarına bakılmıştır. Kruskal Wallis H-Testi sonuçları Tablo 1'de yer almaktadır.

Kruskal Wallis H-Testi sonuçlarına göre $\mathrm{H} 2$ ve $\mathrm{H} 3$ için muhasebe meslek mensuplarının doğru mesleği tercih ettiklerini düşünmeleri ile bu hipotezlerde belirtilen sorunlar arasında anlamlı bir farklılık olduğu tespit edilmiştir. Doğru mesleği seçtiklerini düşünenlerle düşünmeyenler arasında, meslek mensuplarının aldıkları ücretlerin emeklerinin karşılığı olması durumu ve mükelleflerden aldıkları ücretleri zamanında veya hiç tahsil edememeleri arasında anlamlı bir farklılık vardır. Buna göre emeklerinin karşılığı olan ücreti alan meslek mensupları ile tahsilat sorunu yaşamayan meslek mensuplarının mesleki memnuniyet düzeyleri daha yüksektir

\section{SONUÇ}

İşletme ile ilgili taraflara bilgi üretmeye çalışan muhasebe meslek mensupları çeşitli sorunlarla karşı karşıya kalmakta ve bir takım beklentiler içerisine girmektedirler. $\mathrm{Bu}$ çalışmada; muhasebe meslek mensuplarının karşılaştıkları sorunlar ve sorunların çözümüne yönelik olarak beklentilerini tespit amacıyla Uşak ilinde faaliyet gösteren muhasebe meslek mensuplarına anket çalışması uygulanmıştır. $\mathrm{Bu}$ sebeple çalışmada muhasebe meslek mensuplarına mesleki sorunlarını ve mükelleflerden, devletten, Mali Müşavirler Odası'ndan, TÜRMOB’dan, KGK’dan beklentilerini belirlemeye yönelik sorular yöneltilmiştir. Ayrıca muhasebe meslek mensuplarının mesleki memnuniyetleri ölçülmeye çalışılmıştır.

Uşak ilinde faaliyet gösteren muhasebe meslek mensuplarının çoğunluğunu erkekler oluşturmaktadır. Yaş olarak yoğunluk 31-50 yaş arasında toplanmıştır. Anket sonuçlarına göre, genç nüfusun mesleği tercih etmediği veya staja başlama ve SMMM sınavlarındaki başarının az olduğu söylenebilir. Yine ankete katılan mensupların çok az bir kısmının 5 yıldan daha kısa süredir meslekte bulundukları dikkate alınırsa son yıllarda mesleği tercih edenlerin sayısının düştüğü söylenebilir.

Muhasebe meslek mensuplarının genel itibariyle sorunlarına bakıldığında, çok yüksek bir çoğunluk iş yüklerinin fazla olduğundan ve özel hayatlarına zaman ayıramadıklarından, alınan ücretlerin emeklerinin karşılığı olmamasından ve diğer meslektaşlarının mevcut tarifenin altında bir fiyattan defter tutmasından şikayet etmektedirler.

Meslek mensuplarının mükelleflerine ilişkin beklentileri, mükelleflerinin ücretlerini zamanında ve tam ödenesi, belgelerini zamanında ve eksiksiz teslim etmesi şeklindedir.

Uşak ilinde faaliyet gösteren muhasebe meslek mensuplarının devletten beklentileri; bürokratik işlemlerin azaltılması, vergi mevzuatında yapılacak değişikliklerde muhasebecilerin de görüşünün alınması, muhasebe standartlarına ilişkin değişiklikler hakkında bilgi verilmesi, mesleğe hak ettiği değerin verilmesinin sağlamasıdır. 
Muhasebe meslek mensuplarının büyük çoğunluğu Uşak Mali Müşavirler Odası'ndan memnuniyet duymaktadırlar. Beklentileri ise mevzuattaki değişiklikler hakkında bilgi ve yeterli eğitimin verilmesi, resmi kurumlarda karşılaşılan sorunların çözümüne yardımcı olunmasıdır. Meslek mensuplarının TÜRMOB'un muhasebecilerin hakkını savunan bir muhasebe hukukunun oluşturması, mesleğin tanınması için gerekli çalışmalar yapması, KGK'nın muhasebe ve denetim standartlarına ilişkin yeterli bilgilendirme toplantıları yapması beklentisi içinde olduğu tespit edilmiştir.

Yapılan çalışmanın son bölümünde mensupların mesleki memnuniyetleri ölçülmüş, Uşak ilinde faaliyet gösteren mensuplardan ancak \% 59'luk kısmı doğru mesleği seçtiğini düşündüğünü söylemiştir. Yapılan Kruskal Wallis H-Testi sonuçlarına göre; doğru mesleği seçtiklerini düşünenlerle düşünmeyenler arasında, meslek mensuplarının aldıkları ücretlerin emeklerinin karşılığı olması ve mükelleflerden aldıkları ücretleri zamanında veya hiç tahsil edememeleri arasında anlamlı bir farklılık tespit edilmiştir. Buna göre emeklerinin karşılığı olan ücreti alan meslek mensupları ile tahsilat sorunu yaşamayan meslek mensuplarının mesleki memnuniyet düzeyleri daha yüksektir.

\section{KAYNAKLAR}

Alagöz, Ali-Ceran, Yunus (2007). "Muhasebe Meslek Mensuplarının Sorunları, Meslek Örgütünden Beklentileri ile Mesleki Vizyon Algılarını Belirlemeye Yönelik Bir araştırma: Konya İli Uygulaması”, Selçuk Üniversitesi İ̈BF Sosyal ve Ekonomik Araştırmalar Dergisi, Sayı.14, Ekim, ss. 291-312.

Bilen, Abdulkadir (2008), "Doğu Anadolu Bölgesindeki Muhasebe Meslek Mensuplarının Profilleri, Etik Kurallarına Bakışları ve Meslek Sorunları Üzerine Bir Araştırma”, Mali Çözüm, Say1.85,ss. 27-42.

Bilici, Nilgün-Aydemir, A.Fatih (2011), "NUTS II TRA1 Açısından (Erzurum-ErzincanBayburt Bölgesinde) SMMM'lerle İlgili Profil Araştırması ve Karşılaştıkları Sorunlar”, EKEV Akademi Dergisi, Y11.15, S.48, ss. 353-372.

Biyan, Özgür (2012), "Muhasebe Meslek Mensuplarına Yönelik Bir Çalışma: Meslek Mensuplarının Demografik Durumları, Mesleki Sorunları ve Değerlendirilmesi”, Sosyo Ekonomi, S.1, ss. 106-134.

Gökgöz, Ahmet-Zeytin Mustafa (2012), "Muhasebe Meslek Mensuplarının Mesleki Faaliyetlerinde Karşılaştıkları Sorunlar ve Beklentileri: Bilecik ve Yalova İlleri Uygulaması", Süleyman Demirel Üniversitesi İ.İ.B.F. Dergisi, Cilt.17, S.1, ss. 477493.

Kalayc1, Şeref-Tekşen, Ömer (2006), "Muhasebecilik Mesleğinde Karşılaşılan Sorunlar ve Çözüm Önerileri: Isparta İl Merkezi Uygulaması”, Muhasebe ve Finansman Dergisi, S.31, ss. 90-101. 
Karcıoğlu, Reşat-Yazarkan, Hakan (2011), “Muhasebe Meslek Mensuplarının Faaliyetleri Sırasında Kamu Kurumlarında Karşılaştıkları Sorunlara İlişkin Ampirik Bir Araştırma”, Muhasebe ve Denetime Bakış Dergisi, Cilt.11, S.34, ss. 1-12.

Koç, Ayhan, (2011) "Muhasebe Gününde Angaryalara İsyan", ASMMMO Bülten Y.21, S.194, ss. 4-6.

Organ, İbrahim-Yegen, Baki (2013), "Vergi Bilinci ve Vergi Ahlakı Oluşumunda Muhasebe Meslek Mensuplarının Rolü: Adana Örneği”, Atatürk Üniversitesi İktisadi ve İdari Bilimler Dergisi, Cilt.27, S.4, ss. 241-271.

Ömürbek, Vesile - Türkoğlu, Tarık (2013), "Muhasebe Meslek Mensupları Arasında Yaşanan Haksız Rekabet Üzerine Bir Araştırma”, Balıkesir Üniversitesi Sosyal Bilimler Enstitüsü Dergisi, Cilt.16, S.30, ss. 115-149.

Öztürk, Veli - Çil Koçyiğit, Seyhan-Çına Bal-Emine (2009), “Muhasebe Meslek Mensuplarının Bazı Demografik Değişkenleri ile Mesleki Tükenmişlik Düzeyleri Arasındaki İlişki: Ankara İli Örneği”, Muhasebe ve Finansman Dergisi, S.44, ss. 137148.

Özulucan, Abitter - Bengü, Haluk - Özdemir, Fevzi, Serkan (2010), “Muhasebe Meslek Mensuplarının Güncel Sorunları, Uygulamada Karsılaştıkları Yetersizlikler Ve Meslek Odalarından Beklentilerinin Unvanları Ve Mesleki Deneyim Süreleri Yönüyle İncelenmesi: Türkiye Genelinde Bir Araştırma" Muhasebe ve Denetime Bakış, S.31, May1s, ss. 41-64.

Tetik, Nilüfer - Kınay, Fatma - Ciğer, Ayşegül (2008), “Antalya İlindeki Muhasebe Meslek Mensuplarına Yönelik Durum Analizi ve Beklentilerini Saptamaya Yönelik Bir Araştırma”, Muhasebe ve Finansman Dergisi, S.38, ss. 70-79.

Tuğay, Osman - Tekşen, Ömer (2014), “Muhasebe Meslek Mensuplarının Sorunları: Burdur İlinde Bir Araştırma”, Süleyman Demirel Üniversitesi İktisadi ve İdari Bilimler Fakültesi Dergisi, C.19, S.1, ss. 223-232.

Uzay, Şaban - Güngör Tanç, Şükran (2004), "Muhasebecilerin Sorunları ve Beklentileri: Kayseri ve Nevşehir İlleri Uygulaması”, Muhasebe ve Finansman Dergisi. S.22, ss. 94-104.

Yıldırım, Suat - Güney, Selami (2012), “Serbest Muhasebeci Mali Müşavirlerin Genel Sorunları: Erzurum İli Örneği”, Muhasebe ve Denetime Bakış, Nisan, ss. 35-48.

3586 sayılı Serbest Muhasebeci Mali Müşavirlik ve Yeminli Mali Müşavirlik Kanunu, Resmi Gazete, S.20194, 13.06.1989. 